\title{
Topographic controls on plateau icefield recession: insights from the Younger
} Dryas Monadhliath Icefield, Scotland

\author{
Clare M. Boston ${ }^{1 *}$, Sven Lukas ${ }^{2}$
}

${ }^{1}$ University of Portsmouth, Department of Geography, Buckingham Building, Lion Terrace, Portsmouth, PO10 7GW, UK.

${ }^{2}$ Geologiska institutionen, Lunds universitet, Sölvegatan 12, 22362 Lund, Sweden

*Corresponding author: clare.boston@port.ac.uk

\begin{abstract}
Plateau icefields are a common form of mountain ice mass, frequently found in midlatitude to high-arctic regions and increasingly recognised in the Quaternary record. Their top-heavy hypsometry makes them highly sensitive to changes in climate when the ELA lies above the plateau edge, allowing ice to expand significantly as regional ELAs decrease, and causing rapid recession as climate warms. With respect to future climate warming, it is important to understand the controls on plateau icefield response to climate change in order to better predict recession rates, with implications for water resources and sea-level rise. Improving knowledge of controls on glacier recession may also enable further palaeoclimatic information to be extracted from the Quaternary glacial record. We use the distribution of moraines to examine topographic controls on Younger Dryas icefield recession in Scotland. We find that overall valley morphology influences the style of recession, through microclimatic and geometric controls, with bed gradient affecting moraine spacing. Ice mass reconfiguration may occur as recession progresses because ice divide migration could alter the expected response based on hypsometric distribution. These results add to a growing body of research examining controls on glacier recession and offer the potential of unravelling non-linear ice mass behaviour.
\end{abstract}

\section{Keywords}

Plateau icefield, topographic controls, Younger Dryas, glacier recession, moraines 


\section{Introduction}

Plateau icefields are important independent ice dispersal centres during both glacial periods and at present. When the equilibrium line altitude (ELA) is located above the plateau edge, plateau icefields become highly sensitive to changes in atmospheric boundary conditions, since a small increase or decrease in the ELA will lead to a large increase in the size of the ablation or accumulation area, respectively (Furbish and Andrews, 1984; Oerlemans, 1989; Barr and Lovell, 2014). This, combined with shorter response times than for larger ice masses, has resulted in a complex response to climate fluctuations throughout the Holocene (Nesje et al., 2008; Levy et al., 2014; Margreth et al., 2014). During the last glacial these factors likely resulted in plateau icefield expansion ahead of ice sheet advance in regions such as upland Britain, Norway, Arctic Canada and Greenland (Rea and Evans, 2003). Icefields and icecaps have been suggested as representative of 'average' glacial conditions (e.g. Porter, 1989; Hubbard et al., 2009; Evans, 2016; Lukas et al., 2017) during the Quaternary, existing over longer periods of time compared to larger ice sheets (e.g. over North America, Scandinavia and Britain) and consequently have influenced landscape evolution for longer. Under current climate trends existing plateau icefields are becoming increasingly vulnerable to rapid recession as rising ELAs intercept relatively flat plateau source areas (Furbish and Andrews, 1984).

Previous research on the dynamics of plateau icefields has focussed on spatial and temporal changes in thermal regime (e.g. Gellatly et al., 1988; Dyke, 1993; Rea et al., 1998; Evans et al., 2002, 2006), debris erosion and transport (Evans, 2010, de Winter et al., 2012), and modelled predictions of future survival (e.g. Nesje et al., 2008; Giesen and Oerlemans, 2010). More recently, model simulations have investigated non-linear behaviour linked to hysteresis during icefield growth (Åkesson et al., 2017; Zekollari et al., 2017). However, there are currently few studies (for example, Jiskoot et al., 2009) that investigate: 1) factors that influence differences in, and controls on, retreat patterns between outlet valleys, and 2) how an icefield behaves during the final stages of recession once it is constrained to the plateau. Improved understanding of these aspects of icefield recession is important for (i) improving modelled predictions of future icefield response to changes in climate as well as their contribution (rate and magnitude) to sea-level rise in coming decades; (ii) unravelling the complex interplay between climatic, topographic, glaciological and other controls, including outlet glacier evolution during recession, which is crucial to accurately model the dynamics of icemass behaviour through time (cf. Oerlemans, 2008; Rowan, 2011; Åkesson et al., 2017; Zekollari et al., 2017).

One current shortcoming is the relatively short length of modern observations and mass balance series relied on by modelling studies. In order to address these points and offer a fresh perspective, we use the geomorphological record of a Younger Dryas plateau icefield in the Monadhliath, Scotland, (Gheorghiu et al., 2012; Boston et al., 2015), which provides an unprecedented opportunity to examine in detail how topography affected icefield response to changes in climate throughout deglaciation. This approach allows assessment of a full sequence of plateau icefield recession, which likely occurred over several hundred years (Lukas and Benn, 2006). The 
Younger Dryas (12.9-11.7 ka BP; Rasmussen et al., 2006, 2014; Lowe et al., 2008) was a short-lived climatic cooling event that resulted in the expansion of amphi-North Atlantic ice (e.g. Ivy-Ochs et al., 2009; Larsen et al., 2016; Mangerud et al., 2016). In upland Britain, ice mass expansion left a detailed record of well-preserved glacial landforms, in particular moraines (Chandler et al., 2019a, b; Bickerdike et al., 2018a and references therein). The Younger Dryas record in Scotland is therefore important for examining the response of ice masses to rapid climate change at the end of the Last Glacial-Interglacial Transition (LGIT).

Moraines that form at a glacier margin are particularly useful for assessing glacier response to changes in climate, since they provide a record of the glacier terminus position at the time of formation. Ice-marginal moraines are deposited during a glacier advance or period of margin stability, forming sequences of inset moraines where younger moraines form inside previously-formed moraines, creating recessional moraine sequences (e.g. Price, 1970; Benn, 1992; Evans and Twigg, 2002; Lukas and Benn, 2006; Lukas, 2012; Chandler et al., 2016). Such moraine sequences not only indicate that recession was punctuated by minor advances and stillstands (active recession; cf. Boulton, 1986; Benn et al., 1992; Lukas, 2005; Benn and Lukas, 2006; Bickerdike et al., 2018b), but also provide a detailed record of successive ice-marginal positions during overall recession. Whilst some removal of moraines through proglacial and paraglacial processes is possible, meaning that the moraine sequences represent a minimal record of glacier fluctuations, this appears less pronounced during the Younger Dryas in Scotland, where moraines are often densely spaced and evidence of postdepositional erosion is largely absent (e.g. Benn, 1992; Lukas, 2005; Lukas and Benn, 2006; Boston, 2012). With this caveat in mind, the distribution of these moraines can provide an important spatial record of glacier response to changes in climate that may not be captured by point-records such as lake sediment cores alone (e.g. Lukas and Benn, 2006). The aim of this paper is therefore to use moraine sequences in the Monadhliath to systematically assess patterns of differential outlet glacier recession, and to examine the extent to which topography and other factors may have controlled this response. This work is important for 1) understanding the response of ice masses to rapid climatic change during the Younger Dryas, 2) predicting the response of current icefields to future climate warming, and 3) providing valuable insights into controlling factors that currently may not be fully captured by glaciodynamic models.

\subsection{Study area}

The Monadhliath is an upland area in the central Scottish Highlands, consisting of an expansive plateau with rounded summits, approximately 600 to $900 \mathrm{~m}$ above Ordnance Datum (OD). In the south, summits reach altitudes of over $900 \mathrm{~m} \mathrm{OD}$, but are limited to $700-800 \mathrm{~m}$ OD in the north, leading to an asymmetric plateau with short, steep catchments draining south, and larger gently grading catchments towards the north (Fig. 1). The plateau is composed of Late Precambrian psammites and semipelites (Grampian Group), with Silurian-age igneous intrusions of granite, microdiorite and granodiorite forming many of the higher summits (Stephenson and Gould, 1995). 
Extensive geomorphological mapping has previously been undertaken in the area, resulting in the reconstruction of a $\sim 280 \mathrm{~km}^{2}$ Younger Dryas plateau icefield (Boston, 2012; Boston et al., 2015; Boston and Lukas, 2017) (Fig. 1). ELAs calculated using an AABR of $1.9 \pm 0.81$ (Rea, 2009) range between $560-646 \mathrm{~m}$ in the west and 738-814 $\mathrm{m}$ in the east, demonstrating a precipitation gradient across the area (Boston et al., 2015). All ELAs are located either on the plateau ice surface or on the valley backwall close to the plateau edge, meaning the icefield would have been sensitive to small fluctuations in climate. The geomorphological evidence documented suggests that the icefield was polythermal, with plateau ice and some smaller, thinner, outlet glaciers interpreted as cold-based, major outlet glaciers warm-based, and remaining outlet glaciers potentially polythermal (Boston et al., 2015). This is based on glacial landforms identified on the plateau and within outlet valleys ranging from ice-marginal meltwater channels only (cold-based ice; Dyke, 1993) to densely-spaced moraines (warm-based ice; Benn and Lukas, 2006). Bed gradient and ice thickness appear to have had a major control on glacier thermal regime, since the cold-based outlet glaciers were thin and resided in low gradient valleys with no backwall, compared to major outlet valley glaciers that were much thicker and connected to the plateau via steep backwalls (Boston et al., 2015). In this paper we focus on the major outlet valleys since they contain densely-spaced moraines and hence provide the most complete record of recession.

\section{Methods}

The moraines were mapped as part of a wider Quaternary glacial geomorphological mapping campaign (Boston, 2012) using a combination of field mapping, aerial photograph stereopairs, and the NEXTMap Great Britain DEM (Intermap Technologies, 2007), following the approach outlined in Chandler et al. (2018). The Younger Dryas outlet glacier maximum limits were identified using morphostratigraphy (cf. Lukas, 2006). This approach uses changes in the morphology of a range of landforms (e.g. moraines, river terraces, talus slopes, solifluction lobes) to identify a glacier limit on the basis that a different fluvial and periglacial process history would have occurred inside and outside the glacier limits. The application of this approach has been successful for the Younger Dryas in Scotland and is described in detail in Boston et al. (2015) in relation to Younger Dryas glaciation in the Monadhliath.

The majority of Younger Dryas moraines in the Monadhliath take the form of mounds and ridges that are aligned along chains that trend obliquely downslope. In planform, their crestlines can be connected to form chevron- to parabola-shaped arcs. In common with corresponding findings elsewhere in Scotland, these moraines are interpreted as having formed in an ice-marginal position based on their sedimentological composition and a clear linearity in the moraine chains which are orientated to reflect former ice margins (Benn et al., 1992; Bennett and Boulton, 1993; Lukas, 2005; Boston and Lukas, 2013). However, small areas of moraines on the plateau do not have any clear trends in relation to the underlying topography and are therefore interpreted to result from isolated areas of ice stagnation (Boston, 2012; cf. Benn, 1992; Benn et al., 1992). Where the moraines were interpreted as ice-marginal, former ice fronts of major outlet glaciers were reconstructed by linking the moraine 

Hubbard, 2005; Lukas and Benn, 2006; Finlayson et al., 2011; McDougall, 2013). Working upvalley from the maximum Younger Dryas limit of each glacier, clearly identifiable chains of moraines, often further defined by intervening meltwater channels (not shown in Fig. 2 due to map scale), were linked together by interpolating the moraine crestlines. Inset moraine arcs were assumed to have been subparallel to the maximum former ice margin based on the pattern that emerges at most modern glaciers where annual/minor moraine sequences are formed (e.g. Lukas, 2012; Reinardy et al., 2013; Chandler et al., 2016; and references therein). Moraine bifurcations, where a single moraine splits in two, were drawn when a crestline subdivided within an individual ridge complex in a downvalley direction or when the gradient of two chains of lateral or latero-frontal moraines converged in an upvalley direction. Where lateral moraines were more abundant than frontal moraines, the reconstructed lateral ice margins were extrapolated across the valley floor arcuately, following a projection set by the orientation of the lateral moraine chain and the valley side gradient. Ice margins were joined from one valley side to the other when the reconstructed lateral ice margin matched a lateral ice margin on the opposite side based on altitude and ice-surface gradient. The aim was to connect the moraine fragments to create a symmetrical ice front similar to moraine sequences found in modern environments (e.g. Lukas, 2012; Chandler et al., 2016), although it is recognised that modern ice fronts are not always symmetrical (e.g. Thome, 1972). We acknowledge that there is subjectivity to this approach, but we are confident that the general pattern of ice fronts produced (i.e. areas of densely-spaced ice fronts vs areas where few ice fronts were drawn) reflects the spatial distribution of moraines. The former ice fronts identified are shown overlain on the moraines (as in Fig. 2) for all valleys in Figures S1-15 of the Supporting Information.

The spacing between reconstructed ice margins was assessed by measuring the distance between each margin along the inferred central glacier flowline. A 'barcode' diagram was then produced in order to represent distances visually, where each vertical line represents a former ice front (cf. Lukas and Benn, 2006). All barcodes start at the Younger Dryas maximum glacier position in each valley (cf. Lukas and Benn, 2006), allowing the pattern of recession from this position to be assessed for each outlet glacier. We recognise, that the outlet glaciers are unlikely to have reached their maxima synchronously (cf. Golledge et al., 2008; Hubbard et al., 2009; Åkesson et al., 2017; Seguinot et al., 2018), and thus wish to emphasise that our analysis is focussed on topographic controls rather than an attempt to link directly to climate forcing, since evidence for when Younger Dryas glaciers reached their maximum positions is conflicting (e.g. Macleod et al., 2011, 2015; Bromley et al., 2014; Small and Fabel, 2016).

\section{Results}

\subsection{Planform distribution of former ice margins}

Description: The reconstructed ice margins document recession patterns of 16 major outlet glaciers sourced by the Younger Dryas Monadhliath Icefield (Fig. 3 and SI Figs. S1-15). The ice margins are generally parabolic or chevron-shaped in planform and in 
some valleys continue onto the plateau (Fig. 3). In many valleys, the pattern of ice margins documents division of main valley glaciers into tributary glaciers as recession progresses. The moraines often display crestline bifurcations, either directly or that can be implied from the converging orientations of two separate moraine ridges. In a number of cases lateral moraines with distinct crestlines are superimposed, but this is not portrayed by the reconstructed ice margins which only depict crestlines. Truncated/cross-cutting ice margins are also reconstructed from the pattern of moraines within two valleys, Glen Chonnal and Corrie Yairack (Fig. 4).

Interpretation: The orientation of moraines indicates that outlet glaciers predominantly retreated towards and into their respective plateau source areas. However, four valleys (Shesgnan, Yairack, Lochain and Ballach) are identified where the ice may have either partly or fully disconnected from the plateau during the final stages of retreat, forming small valley head cirque glaciers and retreating independently from plateau ice. This interpretation is made for valley heads where moraines are found close to the valley backwall, but not on the plateau, and there is a potential ice detachment zone, i.e. where ice would have been thin over the plateau rim (Fig. 5).

The close spacing of moraines within the majority of valleys indicates an oscillatory style of Younger Dryas glacier recession, characterised by minor readvances and stillstands, as has been identified in other areas of Scotland (e.g. Benn et al., 1992; Lukas and Benn, 2006; Finlayson et al., 2011). This record of recession has previously been interpreted to imply that the former glaciers remained close to equilibrium during a large proportion of recession (Ballantyne, 2002; Lukas and Benn, 2006). Alternatively, stochastic annual variability in mass balance could also produce a similar pattern of moraine spacings (Anderson et al., 2014). It is also noteworthy that this geomorphological record of oscillatory retreat is not as prevalent in the Monadhliath as a whole, due to the range of thermal regimes described in Section 1.1 (Boston et al., 2015).

In most valleys the ice margins, albeit with bifurcations, are set one inside the other. This pattern of predominantly inset margins suggests that any readvances were not significant enough to override or destroy previous moraines, indicating more or less continuous recession. However, in Glen Chonnal and Corrie Yairack, the only way to explain the moraine pattern is to truncate/cross-cut some ice margins (Fig. 4; SI Figs. S5, S15), indicating that a more substantial glacier advance interrupted overall recession in these valleys. In Glen Chonnal, the truncated ice margins suggest both the Dubh and Creag a' Chail glaciers readvanced after separation (Fig. 4a). These readvances may have been a response to this geometric change, decreasing the response times of the now smaller ice masses and enabling a more sensitive response to changes in climate. Specifically, the readvance of the Creag a' Chail Glacier prior to the Dubh Glacier readvance indicates a faster response time of the smaller glacier, as observed in modern neighbouring glacierised catchments (Kuhn et al., 1985). Similarly, we suggest that an advance of the Corrieyairack Pass Glacier occurred following separation from ice in the main valley (Fig. 4b). At this stage in recession, the Yairack Glacier had receded into the head of Corrie Yairack (possibly detaching from plateau ice above) and the reconstructed ice margins indicate that the 

previously-formed moraines.

Based on our interpretation of the moraine patterns, crestline bifurcations occur regularly within the outlet valleys examined (Figs. 3, 4). Bifurcations are caused either by spatial variations in ice-marginal retreat or advance rates, and the process produces a new moraine at a subsequent, inset margin, which is adjoined to the original moraine in areas where the ice margin has remained more or less stable (or readvanced to the same position), creating a 'forked' moraine (e.g. Bennett and Boulton, 1993; Lukas, 2003; Benn and Lukas, 2006; Iturrizaga, 2008; Chandler et al., 2016). In the Monadhliath, two forms of bifurcation are identified. Firstly, a bifurcation in the latero-frontal part of the moraine (which we term 'frontal' henceforth), caused by more melting at the glacier snout (at lower elevations) than surface thinning further upglacier (Fig. 6a). This pattern of moraines is observed at modern valley glaciers, for example in the European Alps, where a second latero-frontal moraine is superimposed processes often remove subsequent lateral moraines (e g. Curry et al.,2006) and peat cover in ancient settings may give the appearance of only one lateral moraine. In the Monadhliath most valley sides are not particularly steep and a sequence of inset lateral moraines is often observed, including superimposed lateral moraines which have distinct crestlines. Equally, paraglacial reworking has been demonstrated effective only on landforms located outside the Younger Dryas glaciation limits due to rapid warming and re-vegetation at the start of the Holocene (Bennett, 1999; Lukas, 2005, 2007a; Benn and Lukas, 2006).

Secondly, bifurcations of the lateral moraine are seen in a number of valleys, particularly close to the plateau or plateau backwall (Fig. 6b). Since the ELA would have been located on the plateau ice surface at this stage in recession, these bifurcations represent recession of the plateau ice margins in conjunction with recession of the outlet glacier. In other areas the lateral bifurcations occur closer to the maximum outlet glacier extent (Fig. 6c), and we suggest that these bifurcations were a result of minor advances causing part of the glacier tongue to cross-cut previously deposited moraines (Bennett and Boulton, 1993) (Fig 6c). Based on the pattern of ice fronts, we identify three styles of glacier recession relating to bifurcations in the Monadhliath: recession dominated by 1) frontal bifurcations, 2) lateral bifurcations, and 3) both frontal and lateral bifurcations (Fig. 6d). As lateral bifurcations cannot be captured along transects, the 'barcode' approach described below only accounts for frontal bifurcations.

\subsection{Spacing of former ice margins}

Description: The 'barcodes' generated from the map of former ice margins allow an assessment of the spacing between moraines for the 16 outlet glaciers selected (Fig. 7). The number of ice-marginal positions ranges from 12 in Shesgnan Cùil to 99 in Findhorn Abhain Crò Chlach. Typical distances between moraine crestlines in densely-spaced areas vary between $10 \mathrm{~m}$ and $60 \mathrm{~m}$, whilst larger gaps between ice margins are $>1 \mathrm{~km}$. Upvalley of the Younger Dryas maximum position (shown on right in Fig. 7), it is clear that the pattern of glacier recession (barcode) is individual to each 
valley. This is seen both immediately inside the Younger Dryas limit and further upvalley where separating tributary glaciers have produced different distances between moraines.

Interpretation: The distances $(10-60 \mathrm{~m})$ between moraine crestlines are similar to distances on Skye (Benn, 1992) and in the Northwest Highlands (Lukas and Benn, 2006), and recently-formed annual moraines in Europe (Lukas, 2012; Reinardy et al., 2013; Chandler et al., 2016). The number of ice margins (12-99) is significantly lower than recognised in the Northwest Highlands (53-210; Lukas and Benn, 2006), however. Lukas and Benn (2006) suggested that, in the latter region, moraines were formed every 3-23 years based on an estimated 600-1200 years available for retreat. We do not make this calculation here, since the timing of Younger Dryas maximum glacier extent is uncertain (e.g. Benn et al., 1992; Lukas and Bradwell, 2010; Ballantyne, 2012; Macleod et al., 2011, 2015; Bromley et al., 2014; Small and Fabel, 2016; Peacock and Rose, 2017).

Despite the aforementioned differences in moraine spacing between valleys, some broad patterns are evident, particularly over the outermost kilometre of each transect (i.e. immediately inside the Younger Dryas limit), and based on this we divide the barcodes into three key groups, which we term recession types 1,2 and 3. The divisions are not absolute, since each barcode is unique, but they allow some generalisation of the recession patterns immediately inside the Younger Dryas limit. We refer to these as the outermost evidence of recession and subsequently contrast them with the innermost (upvalley) patterns that would have occurred following extensive recession. This acknowledges that we do not have good control on the absolute timing of events during recession, which makes the use of terms such as 'initial' and 'late' stages of retreat (cf. Lukas and Benn, 2006) problematic.

Former glaciers that exhibit recession type 1 produced outermost successions of closely-spaced moraine arcs, before subsequently receding greater distances between episodes of moraine production. Within recession type 2, larger distances occur between ice margins immediately inside the Younger Dryas maximum, which reduce at various locations further upvalley. In contrast, within type 3 , ice margins are more evenly spaced throughout, with no distinct clusters.

\subsection{Innermost stages of recession}

Description: The innermost ice fronts (Fig. 3) document the last stage during recession at which moraines were formed and preserved at each outlet glacier. The outlet glaciers were reconstructed for this stage of recession (Fig. 8), illustrating that glacier ice in some catchments was still extensive, compared to other areas where small ice masses in topographic hollows were still able to produce moraines. As stated earlier, some outlet glaciers may have disconnected from their plateau source areas to form cirque glaciers (e.g. Yairack, Shesgnan, Lochain and Ballach) and continued to form moraines (Figs. 3b, 3d, 5; SI Figs. S1, S12, S13, S15).

Interpretation: It is likely that the innermost ice fronts were reached asynchronously because the size and extent of ice across neighbouring catchments is not mirrored across the ice divide (e.g. Fig 7: Easgainn - Killin Odhar, Lagan a' Bhainne - Chonnal, 
Findhorn Eskin - Killin Markie). This suggests that some outlet glaciers began receding rapidly and/or downwasting passively, without forming moraines, whilst neighbouring glaciers continued to recede actively. In general, the innermost ice fronts are furthest from the ice divides in areas with large plateau catchment areas and where outlet valleys are connected to the plateau via gentle slopes. In these areas recession was likely to have been rapid in the final stages (Giesen and Oerlemans, 2010), which may have begun initially by a period of ice thinning prior to a significant reduction in ice area (Gordon et al., 1995). Conversely, in topographic lows on the plateau and in cirques below the plateau rim, some shading and accumulation of wind-blown snow may have provided buffering from regional climate trends (López-Moreno et al., 2006), allowing ice in these areas to continue receding actively for longer.

\section{Controls on recession patterns}

The differences between catchments in terms of outermost recession type, bifurcation controls (glaciological, topographic or otherwise). This is important in order to assess the role of the plateau source area, ultimately to understand the forcing of Younger Dryas climate on the dynamics of glacier recession (cf. Lukas and Bradwell, 2010; Boston et al., 2015). The analysis below focuses on possible controls on recession patterns and style that are independently recognised as important factors in modern settings: general valley morphology, bed gradient, glacier hypsometry and catchment area reconfiguration, and glacier thermal regime. Aspect and underlying geology were also examined but were found not to have a significant effect, although north-facing glaciers tend to have slightly lower ELAs at the Younger Dryas maximum (Boston et al., 2015). Glacier response times will also have affected the pattern of recession (Kirkbride and Winkler, 2012), but assessing any differences in detail is beyond the scope of the data presented, since we do not have good control on former ice margin ablation rates that would be required to calculate former response times.

\subsection{Valley morphology}

By assessing the pattern of ice margins (Fig. 3) and the barcodes (Fig. 7) in the outermost areas, we observe that there is an obvious link between the previously identified outermost recession types and bifurcation styles, which can then be related to the morphology of the outlet valley. The closely-spaced ice margins within recession type 1 are often caused by frontal bifurcations (Fig. 6a) indicating a sensitive response of the glacier snout to changes in mass balance. This pattern of recession is predominantly found in long, narrow ( $200 \mathrm{~m}$ valley floor width) outlet valleys with steeper sides. This may be partly linked to the fact that a narrower glacier tongue will produce larger changes in length to accommodate the same change in volume compared to a wider glacier (Barr and Lovell, 2014; Mackintosh et al., 2017), thereby making the position of the glacier snout particularly sensitive to changes in glacier mass balance.

In contrast, far fewer former ice margins were reconstructed within recession type 2, in part due to a limited number of frontal bifurcations. Only three neighbouring outlet valleys (Chaorainn, Fionndrigh and Lochain; Fig. 3d) were identified with this 
recession type, since the majority of moraine sequences are characterised by closelyspaced moraines immediately inside each Younger Dryas limit (recession types 1 and 3). Of the valleys, Chaorainn and Lochain are over $500 \mathrm{~m}$ wide, whilst Fionndrigh is narrow. Moraine patterns within Fionndrigh exhibit frontal bifurcations similar to other narrow valleys described above, yet there are fewer moraines near the Younger Dryas maximum than in other valleys. Conversely, moraines in Chaorainn and Lochain display lateral bifurcations within their outermost recession sequences, similar to other wide valleys, e.g. Ballach, Larach and Chonnal (all recession type 3) (Fig. 6c). This may relate to there being more accommodation space within wider valleys to allow small advances of different parts of the ice margin, compared to narrower valleys where the ice is funnelled through the valley centre to a greater extent. Differences in insolation between narrower valleys (more shaded) and wider ones (less shaded) may also account for some of the differences in response between valleys.

Recession type 3, despite showing more uniform spacing of former ice fronts along the glacier centreline, contains both frontal and lateral bifurcations (Fig. 6d), indicating that localised rates of recession or minor advance at the glacier margin were highly variable, producing a complex ice-marginal response. This style of recession is often found in outlet valleys where the Younger Dryas maximum limit is either close to the plateau edge (e.g. Easgainn, Larach) or within wide (>500 m valley floor width) topographic depressions (proto-valleys) on the plateau (e.g. Lagan a' Bhainne, Chonnal), where there is no obvious transition from valley to plateau. The former consist of short $(\sim 1 \mathrm{~km})$ outlet glaciers which were fed by plateau ice converging from a range of directions. As suggested in Section 3.1, the pattern of moraines appears to have been controlled by both active recession of the outlet glacier (producing frontal bifurcations) and recession of ice on the plateau (producing lateral bifurcations) once the ELA was located above the plateau edge. This resulted in both bifurcation styles and a closely-spaced succession of former ice margins. Within the plateau protovalleys, local ice flow also converged from a range of directions close to the glacier margin, providing greater potential for both types of bifurcation.

\subsection{Glacier bed gradient}

Glacier bed gradient is known to have a pronounced effect on glacier recession rates (Oerlemans, 1989, 2012; Barr and Lovell, 2014). This is because, on topographicallyconstrained glaciers, the glacier surface profile is mainly controlled by the gradient of the underlying topography. Thus, a small vertical rise in the ELA (e.g. $10 \mathrm{~m}$ ) will cause a larger increase in ablation area size on a glacier with a low surface profile, compared to one with a steeper gradient (Kuhn et al., 1985; Oerlemans, 2012; Giesen and Oerlemans, 2010; de Winter et al., 2012) (Fig. 9). This will translate to a larger distance of terminus recession on flatter topography compared to steeper slopes, where a smaller increase in the ablation area would occur. In this section, we consider the effect of glacier bed gradient within the wider context of valley morphology in order to examine its smaller-scale control on the spacing of former ice-fronts.

An initial comparison of the recession patterns within the outlet valleys for the three outermost recession styles (Fig. 10) shows that the effect of overall valley morphology (Section 4.1) on glacier recession patterns is augmented by smaller-scale changes in 
bed slope gradient: moraines are generally spaced closer on steeper slopes compared to those on lower-gradient topography. This occurs despite the ELA being already located on the flatter plateau ice surface at the time (see Section 1.1). The effect of glacier bed gradient on moraine spacing is then assessed further by plotting the full barcode recession sequence for each glacier on its valley long profile, and comparing with the initial glacier hypsometry (Fig. 11). This shows that the gradient of the glacier bed has a large influence on moraine spacing throughout recession, not just in the outlet valleys and initial transition onto the plateau. This influence is pronounced enough to enable outlet glaciers to be grouped according to their bed topography and overall recession style as follows (Fig. 11):

1. Catchments with a backwall (BW) - There are six outlet valleys in which moraine deposition stops close to the base of a steep backwall that connects the valley to the plateau. These valleys have very little contributing plateau area $(<20 \%$ of the total glacier area at the Younger Dryas maximum, with the exception of Yairack (1a; $\sim 50 \%$ ) and Lagan a' Bhainne (1f; (> 80\% since the glacier is in a proto-valley with backwall)). In some, we interpret the moraine pattern to indicate that valley ice disconnected from plateau ice as deglaciation progressed (Fig. 5).

2. Catchments with moraines on the plateau (PM) - There are nine catchments that do not have steep backwalls and have large plateau source areas with moraines (in general, over $80 \%$ of the total glacier area at the Younger Dryas maximum is on the plateau). Plateau moraines often occur as isolated clusters in proto-valleys compared to more continuous zones of moraines in the lower parts of the valley.

3. Catchments with no moraines on the plateau (PNM) - Six catchments have large plateau source areas (50 - 90\% of the total glacier area at the Younger Dryas maximum), but do not have recessional moraines on these plateaux. Some of these catchments also have a backwall (BW).

4. Catchments with transection valleys (V) - Three valleys dissect the Monadhliath plateau and would have hosted transection glaciers during icefield recession. In these catchments a large plateau source area existed at the Younger Dryas maximum extent, but as the outlet glacier receded a simultaneous disconnection with the contributing plateau ice occurred, depriving the glacier from much of this source area. Moraines in these catchments generally occur in the valley only, although some occur towards the head of Glen Markie (Killin) (4c) where there is no steep backwall.

Across all four groups, outlet valleys with consistent gradients tend to have more evenly distributed moraines (e.g. Fig. 11: Yairack Coire (1a), Shesgnan Coire (1d), Chonnal Coire Chail (2a), Chonnal West (2c)), whilst moraine density varies in valleys with significant changes in gradient (e.g. Fig. 11: Uchdachan (1c), Brein (2e), Killin Markie (4c)). Within outlet valleys, former ice fronts are reconstructed on slopes between $5^{\circ}$ and $20^{\circ}$. With the exception of Killin Eich $(2 \mathrm{~g})$, moraines were either not formed or preserved on slopes $>20^{\circ}$, suggesting either a reduction in ice margin stability or a dominance of paraglacial slope processes. Close to or on the plateau, ice fronts are only reconstructed on slopes $>5^{\circ}$. We suggest that moraine removal through 
paraglacial slope processes is unlikely in these areas due to low relief energy and inherent climatic boundary conditions as explained in Section 3.1. Therefore, moraines probably did not form here due to either rapid recession, a change in ice-marginal processes potentially linked to thermal regime or a reduction in ice margin steepness (e.g. Lukas, 2012; Bradwell et al., 2013). The ice did not encounter any major reverse bed slopes in the study area (overdeepenings along flowpaths are rare) and likewise, few lateral topographic pinning points (i.e. where the valley narrows) are observed; recession is more continuous with changes in slope gradient controlling the spacing of moraine sequences.

The most significant change in slope gradient predominantly occurs where outlet valleys meet the plateau, characterised by an increase in slope gradient at the backwall followed by a decrease on the plateau. Few moraines were deposited on backwalls with gradients $<20^{\circ}$, despite forming on these gradients immediately inside the maximum extent. This may imply that, for many catchments, recession close to the plateau had become less active and/or was no longer interrupted by stillstands. This interpretation is supported by the reduction in meltwater channels in these areas (the presence of which would also indicate ice-marginal stability) and by chaotic moraines on the plateau above glens Odhar, Eich and Talagain in areas with slope gradients of $<5^{\circ}$, which have been interpreted to document ice stagnation (Boston, 2012) (Fig. 3a). In contrast, in catchments where ice-marginal moraines were deposited on the plateau, the slope tends to be steeper $\left(5-10^{\circ}\right)$ (Fig. 11) and/or the glaciers have retreated into topographic hollows/proto-valleys and cirques. In such locations some shading and potential for accumulation of wind-blown snow may contribute to longer-lasting active recession, as discussed in Sections 3. 3 and 5.2.

\subsection{Glacier hypsometry and catchment reconfiguration}

499

500

The hypsometry of glaciers in the study area is typical of plateau icefield outlet glaciers, with a large proportion of glacier area at high elevations (Furbish and Andrews, 1984; $95 \%$ of the total area occurs within the upper $50 \%$ of their altitudinal envelopes, whilst catchments with backwalls generally have lower percentages in this band $(60-80 \%)$ (Fig. 11). This distribution of ice will produce an exaggerated response of comparatively narrow outlet glaciers to any mass balance changes (Oerlemans, 1989; Rea and Evans, 2007; Barr and Lovell, 2014; Mackintosh et al., 2017), resulting in greater length changes. Furbish and Andrews (1984) suggest that glaciers with similar hypsometric distributions should in the long-term respond similarly to the same (regional) climatic conditions, yet catchments with a higher percentage area of plateau ice exhibit all three recession styles in their outermost areas, demonstrating the importance of valley morphology and bed gradient in this zone for influencing glacier response to changes in mass balance (cf. Kuhn et al., 1985; Bahr et al., 1998). This top-heavy hypsometric distribution also implies rapid, uninterrupted recession once the ELA intercepts the flat part of the hypsometric curve, which is evidenced by the limited number of moraines on the plateau in general (Jiskoot et al., 2009). However, moraines with a clear spatial pattern, indicative of active recession, are produced in 

and/or forms topographic hollows.

We also find it difficult to link glacier hypsometry at the maximum Younger Dryas extent to variations in recession patterns, since the shape, and thus hypsometric distribution of many of the outlet glaciers, changes significantly during recession (dynamic response: Raper and Braithwaite, 2009; Paul, 2010; Marzeion et al., 2014). For example, at its maximum extent, the Findhorn Glacier (Figs. 3, 10: 4a, 4b) was sourced from a large area of plateau, but the reconstructed ice margins show that the glacier receded into Abhainn Crò Chlach, a proto through-valley, comprising only a small area of plateau between it and Glen Markie to the south. Therefore, as the Findhorn Glacier receded into this valley it would have also lost large areas of its lower tributary plateau source simultaneously, causing a reconfiguration of the hypsometric distribution (Fig. 8). This meant that the ELA would not have reached the flatter part of the hypsometric curve until much later in recession than initially predicted by the hypsometric curve. This reconfiguration, alongside shading from the valley sides is therefore likely to have stabilised recession in this case, allowing active recession and moraine production to continue for longer (Paul, 2010; Marzeion et al., 2014).

There is also evidence for ice reconfigurations where ice may have become cut off from the plateau resulting in loss of valuable accumulation area as identified in Section 3.1 (Fig. 5). Here, ice remained capable of producing moraines indicating at least an initial period of active recession during/following detachment. At other sites, it is also possible detachment occurred followed by immediate stagnation/rapid deglaciation, but by nature, the absence of evidence (moraines) does not elucidate this further. Reconfigurations of glacier hypsometric distribution during recession, which may or may not be linked to ice divide migration, are likely to be common in a plateau icefield setting, particularly in areas of more complex terrain, yet have rarely been discussed in the literature (e.g. Dugmore and Sugden, 1991; Sprenke et al., 1999).

\subsection{Changes in icefield thermal regime}

Thermal regime of individual outlet glaciers at the Younger Dryas maximum was controlled by bed gradient and glacier size (Section 1.1; Boston et al., 2015). These differences in thermal regime influenced the types of landforms produced, ranging from ice-marginal meltwater channels to sequences of densely-spaced recessional moraines. Ice on the plateau is argued to have been cold-based at the Younger Dryas maximum (Boston et al., 2015), based on the potential preservation of blockfields (assuming that plateau ice was thick enough to cover some or all of the blockfields) and the significant number of lateral meltwater channels. However, the presence of moraines in numerous plateau areas indicates that in these areas ice may have been warm-based or polythermal throughout or at least during the later stages of recession. The persistence of warm-based active ice differs from recently documented changes in thermal regime from warm- to polythermal or cold-based (e.g. Lovell et al., 2015; Reinardy et al., 2018) and observed stagnation (e.g. Bradwell et al., 2013) as a result of thinning at modern glaciers. This suggests that in some areas of the Monadhliath plateau, ice remained thick enough to maintain active recession during a likely period of warming temperatures (Brooks et al., 2016). This evidence indicates a both spatially 
and temporally-variable patchwork of thermal regimes and highly-complex thermal and dynamic ice development during both growth and recession (cf. Lukas and Bradwell, 2010).

\section{Discussion}

In order to synthesise the results from this analysis, we present a conceptual model of the topographic controls on polythermal plateau icefield dynamics during both initial and later stages of recession (Fig. 12). The model displays an icefield with a spatially (Fig. 12a) and temporally (Fig. 12b) variable thermal regime that is ultimately controlled by topography and ice thickness: warm-based ice resides in major outlet valleys with steep backwalls and where ice thickness increases to reach pressure melting point, whilst minor outlet glaciers and the majority of the plateau ice are likely to remain cold-based (Fig. 12a). Different styles of warm-based outlet glacier recession are depicted by moraine spacing and bifurcation style, dependent on overall valley morphology and augmented by smaller-scale changes in slope. As outlet glaciers recede towards or onto the plateau, the icefield fragments into smaller outlets that reside both in small proto-valleys on the plateau and as cirque glaciers in valley heads (Fig. 12b). This fragmentation is likely to be diachronous, with glaciers at lower altitudes disconnecting and disappearing first. Whilst some glaciers continue to retreat actively, depositing moraines on the plateau (indicating warm-based or polythermal ice), others form only ice-marginal meltwater channels (potentially indicating coldbased ice), a small number stagnate and others will leave little record of their existence.

The spatial distribution of moraines and the pattern of glacier recession depicted by the moraine barcodes demonstrates that the recession of the Younger Dryas Monadhliath Icefield was modulated by a range of topographic factors, in response to air temperature evolution throughout the Younger Dryas (Brooks et al., 2016) and/or changes in precipitation (Bakke et al., 2009). The topographic controls can be divided into those that affect inputs/outputs to the glacier surface (topographically-linked climatic controls; e.g. snow redistribution by wind and insolation), and those that affect the pattern of recession as a response to changes in glacier mass balance (geometric controls) (Furbish and Andrew, 1984). Below we discuss these controls in more detail before considering the implications of this study for Younger Dryas climate in Scotland and the future response of current plateau icefields.

\subsection{Geometric controls on plateau icefield recession}

The pattern of glacier recession in the Monadhliath indicates outlet glacier response to the same regional changes in climate was heavily influenced by glacier geometry and glacier bed gradient. The influence of slope on glacier recession is well established (Oerlemans, 2012; de Winter et al., 2012; Barr and Lovell, 2014), with larger distances covered annually on flatter slopes and closely-spaced moraines on reverse-bed slopes (e.g. Lukas, 2012; Wyshnytzky, 2017). However, it has rarely been examined in an ancient setting (e.g. Barr and Clark, 2012), which allows a thorough assessment of the influence of topography on glacier recession. These results show that in areas distal $(>1 \mathrm{~km})$ to the plateau, glacier bed gradient was a more important 
control on recession than plateau source area size and glacier hypsometry, with valley/plateau morphology also having an influence on glacier mass-balance through shading and redistribution of snow. This difference in the response of outlet glaciers is particularly apparent where they divided, receding to separate source areas. This implies that these neighbouring glaciers responded differently to the same subsequent climatic variations, due to individual valley morphology and changes in slope gradient, akin to observations on modern glaciers in both glaciated valley and plateau contexts (e.g. Kuhn et al., 1985; Davies and Glasser, 2012; Purdie et al., 2014).

As icefield recession continued, the break-up of plateau ice into smaller ice masses could have given rise to non-climatic stillstands (Greene, 1992; Lukas, 2007b; Reitner, 2007; de Winter et al., 2012). The reasons behind such topographically-controlled or external stillstands can be found in: a) a change in valley cross-section and/or aspect, such as ice retreating from a broad to narrower valley. This leads to a decrease in the surface area exposed to ablation while maintaining the same ice volume, causing stabilisation (Greene, 1992; Barr and Lovell, 2014); b) a division of a large ice mass into two or more smaller ones at valley junctions in complex terrain (e.g. Lukas and Benn, 2006; Lukas, 2007b; Reitner, 2007). This can lead to these glaciers retreating up parallel valleys (e.g. Fig. 3), or can occur during unzipping of two larger ice masses, with potential retreat in opposite directions (Chandler, 2018). Both conditions would lead to the smaller masses being exposed to different boundary conditions (more limited altitudinal range, including a smaller ablation area) than the formerly-coherent ice mass.

Two readvances were identified in the Monadhliath based on the truncation of moraines (Section 3.1) (Fig. 4), that may have been primed by geometrically-controlled stillstands. As the Yairack Glacier receded it separated into glaciers sourced from the head of Corrie Yairack and from the Corrieyairack Pass, a narrow hanging valley leading onto the plateau. As described in a) above, this reduction in valley crosssection surface area within the ablation zone may have caused a stillstand, which allowed the glacier in the Corrieyairack Pass to later advance into Corrie Yairack in response to a subsequent period of positive mass balance. Similarly, in Glen Chonnal, recession into two narrower valleys following tributary glacier separation, could have resulted in tributary stabilisation priming conditions for a subsequent climaticallycontrolled readvance of both. In both examples, differences in microclimatic factors such as shading within the tributary valleys would have contributed to conditions that enabled the subsequent advances (cf. Kuhn et al., 1985), as described below.

\subsection{Topographically-linked climatic controls on ice mass balance}

Topographic shading leading to a reduction in received insolation, alongside snow redistribution by wind, likely also influenced the recession of the Monadhliath Icefield. At the maximum extent, capture of wind-blown snow was probably concentrated in the outlet valleys, immediately below the plateau rim and on north-east facing slopes due to a prevailing south-westerly wind direction (Christiansen, 2004; Bakke et al., 2009; Lane et al., 2013). The potential for wind-blown snow to accumulate on the plateau ice surface at the maximum Younger Dryas extent may have been limited due to a reduction in lee-side slopes, although the plateau breadth is wide enough to have been 
able to capture wind-blown snow (sensu Manley, 1955). Differences in insolation between outlet valleys could also account for variations in glacier response during recession, with moraine spacing and bifurcation style relating in part to valley width and potentially influenced by differences in valley side shading (Sections 3.2 and 4.1 ) (cf. Oerlemans, 1989).

Topography exerted a strong control on glacier response and survival as outlet glaciers receded either into topographic hollows on the plateau or valley heads, forming small cirque glaciers. This resulting distribution of ice is similar to the modelled response of the Norwegian plateau icefield, Hardangerjøkulen, which is predicted to break-up into several small outlet glaciers, and thin into the topographic lows on the plateau, based on where ice is currently thickest (Giesen and Oerlemans, 2010). However, their modelling predicts a rise in the ELA above the plateau, leading to ice stagnation, whilst the presence of moraine sequences in isolated areas on the Monadhliath plateau indicates that these small glaciers were still able to behave actively. Since either a longer-term positive or zero mass balance is required to achieve an advance or stillstand, respectively, each plateau glacier (Fig. 8) must have maintained an accumulation zone during times of moraine production with an ELA located on the glacier surface. Short-lived fluctuations in climate could cause the ELA to lower onto the glacier surface within a longer-term trend for ELAs above the plateau, allowing minor advances or stillstands to occur during an overall pattern of retreat (e.g. Braun et al., 2004), depending on the size and activity state of the ice mass (Bahr et al., 1998). This is likely to have been in combination with enhanced accumulation of snow by wind within proto-valleys and proto-cirques, a reduction in direct insolation due to some shading and/or a geometric reconfiguration (Section 5.1), allowing these marginal ice masses to survive for longer in the most advanced stages of deglaciation.

\subsection{Insights into Younger Dryas palaeoclimate in Scotland}

Younger Dryas climate in Scotland is understood to have been characterised by a cold, arid first half of the stadial, followed by increasing and fluctuating temperatures and precipitation in the latter part (Bakke et al., 2009). The timing of the maximum extent of Younger Dryas glaciation in Scotland is thus critical for understanding the response of glaciers to climate change at this time (cf. Benn et al., 1992; Lukas and Bradwell, 2010; Ballantyne, 2012; Macleod et al., 2011, 2015; Bromley et al., 2014; Small and Fabel, 2016; Peacock and Rose, 2017). Whilst this study can by no means attempt to address these issues, we discuss the style of recession in relation to previous work and with respect to possible timings of maximum extent. Differences in recession patterns between areas in Britain have been discussed recently by Bickerdike et al. (2018b) who identified three styles of retreat: 'active retreat' (spatiallyorganised moraines throughout recession), 'two-stage retreat' (spatially-organised moraines initially with chaotic moraines indicative of stagnation closer to the source area) and 'uninterrupted retreat' (no geomorphological evidence inside the outermost moraines). These authors suggest that the dominance of active retreat across Scotland may support the view that recession began in the mid-stadial, with glaciers responding to a gradual increase in temperatures rather than a more rapid and pronounced increase at the end of the stadial (cf. Benn et al., 1992). 
The reduced number of moraines on the plateau, in combination areas of stagnation, indicates that deglaciation may have switched from oscillatory to uninterrupted retreat, once plateau ice had thinned. Figure 8 demonstrates that there were still large areas of plateau ice in some catchments when moraines ceased forming. However, significant variations occur at catchment level, demonstrated by the asynchronous timing of 'last' moraine production (Section 3.3, Fig. 8), evidence of active recession into proto-valleys or cirques (Fig. 3), and the potential that as ice thinned it became cold-based and ceased forming moraines for this reason. The aforementioned pattern of recession may therefore not be entirely climatically controlled (sensu Benn et al., 1992; Bickerdike, 2018b) and could instead relate to a strong topographic influence on recession in a plateau icefield setting and the potential for 'tipping points' between active and uninterrupted recession. The ability of outlet glaciers to continue producing moraines, almost continuously in many cases, into the final stages of icefield demise indeed suggests that a rapid warming did not cause the uninterrupted recession and stagnation observed elsewhere on the plateau. By examining outlet valleys of consistent bed gradient, the observed even spacing supports Bickerdike's (2018b) view of glacier retreat related to gradually warming temperatures during the late Younger Dryas. However, given the rapidly-changing nature of Younger Dryas climatic parameters (e.g. Lowe et al., 2008; Bakke et al., 2009; Lane et al., 2013; Rasmussen et al., 2014), the timescale of recession is important as to whether large shifts in climate were experienced during icefield retreat.

Evidence for significant readvances during recession is observed at tributary junctions in Corrie Yairack and Glen Chonnal (Fig. 4). These climatically-driven readvances may have been primed by geometrically-controlled stillstands (Section 3.1) following reconfigurations of ice geometry during recession. Similarly, stratigraphic evidence for a minor readvance of ice at the head of Glen Turret late in the stadial following drainage of the Glen Roy ice-dammed lake (see Benn and Evans, 2008; Boston and Lukas, 2017; Palmer and Lowe, 2017), could relate to a short-lived climate fluctuation around this time, or could be a result of a change from a calving to terrestrial ice margin (Benn and Evans, 2008). This limited evidence for significant readvances during overall recession is also identified in the geomorphological record in northwest Scotland where a similar pattern of moraine truncation at valley junctions is observed (Lukas and Benn, 2006). In the northwest, clear sedimentological evidence also exists for partial or full overriding of some moraines (Lukas, 2005), although only full overriding can be distinguished geomorphologically based on crestline flattening. Therefore, the moraine sequences in the Monadhliath represent a geomorphological minimum number of ice-marginal positions due to the potential for some moraines to have been occupied more than once (cf. Lukas and Benn, 2006).

\subsection{Insights into plateau icefield behaviour during recession}

The 'barcodes' which are unique to each outlet valley demonstrate topography exerts a strong influence on glacier recession patterns. In particular, the outermost areas immediately inside the Younger Dryas limits contain evidence that glacier recession was strongly controlled by valley morphology. In the majority of narrow valleys, moraines are closely spaced, and are dominated by frontal bifurcations. By contrast in 
wider valleys, moraines are spaced further apart and exhibit more lateral bifurcations. The recession patterns of outlet glaciers that terminated closer to the plateau edge, often with more gently sloping backwalls, are characterised by closely-spaced moraines and a combination of frontal and lateral bifurcations, which we suggest is a result of simultaneous recession on the plateau and the outlet valley (Section 3.1). Slope gradient also had a significant influence, with former ice margin positions being most closely spaced on steeper slopes. In the Monadhliath this occurs on slopes up to a maximum of $20^{\circ}$, above which moraine formation and/or preservation potential is significantly diminished. These results are similar to recent research on Hardangerjøkulen (Weber et al., in review), which shows that moraine formation over the last century occurred at asynchronously across outlet glaciers as a result of topographic controls and catchment processes. Our examination of moraine patterns and spacing provides one of the few examples of this influence in a Quaternary setting, however.

Our results show that in the outermost areas, the key controls on outlet glaciers are very similar to those of independent valley glaciers. As recession progresses, the influence of plateau source area characteristics is likely to increase in importance. Thus, once outlet glaciers have receded onto the plateau, the icefield response is variable as a result of differences in plateau geometry. Three outcomes are identified here: continuous recession, ice stagnation, and active recession into proto-valleys or proto-cirques. These different scenarios result from variations in slope gradient and the availability of hollows that provide some shading and potential for wind-blown snow accumulation. Ice divide migration and differences in altitude of the plateau are also likely to control differences in rates of recession (Gellatly et al., 1986; Gordon et al., glacier stability, which could allow icefield remnants to survive for longer than current models of icefield recession predict (e.g. Giesen and Oerlemans, 2010). This process is observed at icefields that are currently in the late stages of recession such as the Hazen Plateau ice caps on Ellesmere Island (Braun et al., 2004). These topographically-influenced changes in recession rate corroborate recent modelling results which suggest icefields respond non-linearly to changes in climate (Åkesson et al., 2017; Zekollari et al., 2017). The potential for tipping points during plateau icefield recession is high, where recession rates of outlet glaciers may accelerate or slow down as topographic thresholds are crossed, for example as the outlet glacier recedes from the outlet valley to the plateau rim and then subsequently onto the plateau surface. These tipping points may be reached asynchronously, with the potential for neighbouring outlet glaciers to have stagnating and active ice margins respectively, as a result of variations in outlet valley and plateau morphology.

\section{Conclusions}

The record of Younger Dryas glaciation in the Monadhliath provides a unique opportunity to analyse plateau icefield recession over a longer time period than is otherwise normally possible. Our findings demonstrate a relationship between valley morphology (i.e. slope and width) and patterns of outlet glacier recession. The geometry of the plateau becomes increasingly important as ice margins recede 
towards it. We show that glacier hypsometry, although important for predicting the overall response of ice masses (Furbish and Andrews, 1984; Jiskoot et al., 2009) adjusted during recession in many catchments, making it difficult to reconcile variations in recession patterns observed with glacier hypsometry at the maximum extent. As outlet glaciers receded towards the plateau, some are likely to have disconnected from the plateau source area, receding into valley heads, whilst others receded into topographic hollows on the plateau. In both cases shading and windblown snow accumulation would have allowed ice to survive longer in these areas. In other areas of the plateau, chaotic moraines indicate ice stagnation, whilst an absence of moraines elsewhere suggests more rapid and continuous retreat, as is predicted for flat areas (Furbish and Andrews, 1984; Giesen and Oerlemans, 2010). It is likely that icefield recession was asynchronous, with topography (e.g. altitude, slope and shading) controlling the timing of final icefield demise.

Evidence for a strong topographic control on glacier recession patterns highlights the difficulties of using moraine sequences, such as the ones reported here, in isolation without considering topographic factors to extract detailed climatic information (Kuhn et al., 1985; Greene, 1992; Lukas, 2007b; Barr and Lovell, 2014). By accounting for these topographic factors, we are able to make two key conclusions regarding events during deglaciation in the Monadhliath and Scottish Younger Dryas climate: 1) evidence for major readvances during recession is limited, corroborating findings from the northwest Highlands (Lukas and Benn, 2006), with the potential for both geometric and climatic controls on recession rates, 2) the even spacing of moraines in valleys of consistent bed gradient and the presence of recessional moraines on the plateau suggests that climate warming was gradual rather than rapid, as has been suggested elsewhere (Bickerdike et al., 2018a).

This research complements recent modelling on non-linear recession of plateau icefields (Åkesson et al., 2017; Zekollari et al., 2017), recognising the potential for recession of the Younger Dryas Monadhliath Icefield to have been characterised by threshold behaviour, leading to topographically-controlled rather than climaticallycontrolled stagnation in the later stages. Further work modelling the progression of deglaciation in plateau icefield settings is required to fully integrate topography and climate through time and explore potential topographically-controlled tipping points in detail.

\section{Acknowledgements}

This research is based on field and remotely-sensed mapping undertaken whilst CMB was in receipt of a NERC Algorithm PhD Studentship (NE/G52368X/1) at QMUL. Numerous colleagues are thanked for field assistance and we are grateful to estate owners in the Monadhliath for permission to undertake fieldwork. Jon Merritt is acknowledged for providing access to the aerial photograph collection at the BGS in Edinburgh. We thank Harold Lovell for comments on an earlier draft, the editor, and three anonymous reviewers for detailed reviews that significantly improved the paper. 


\section{$823 \quad$ Figures}

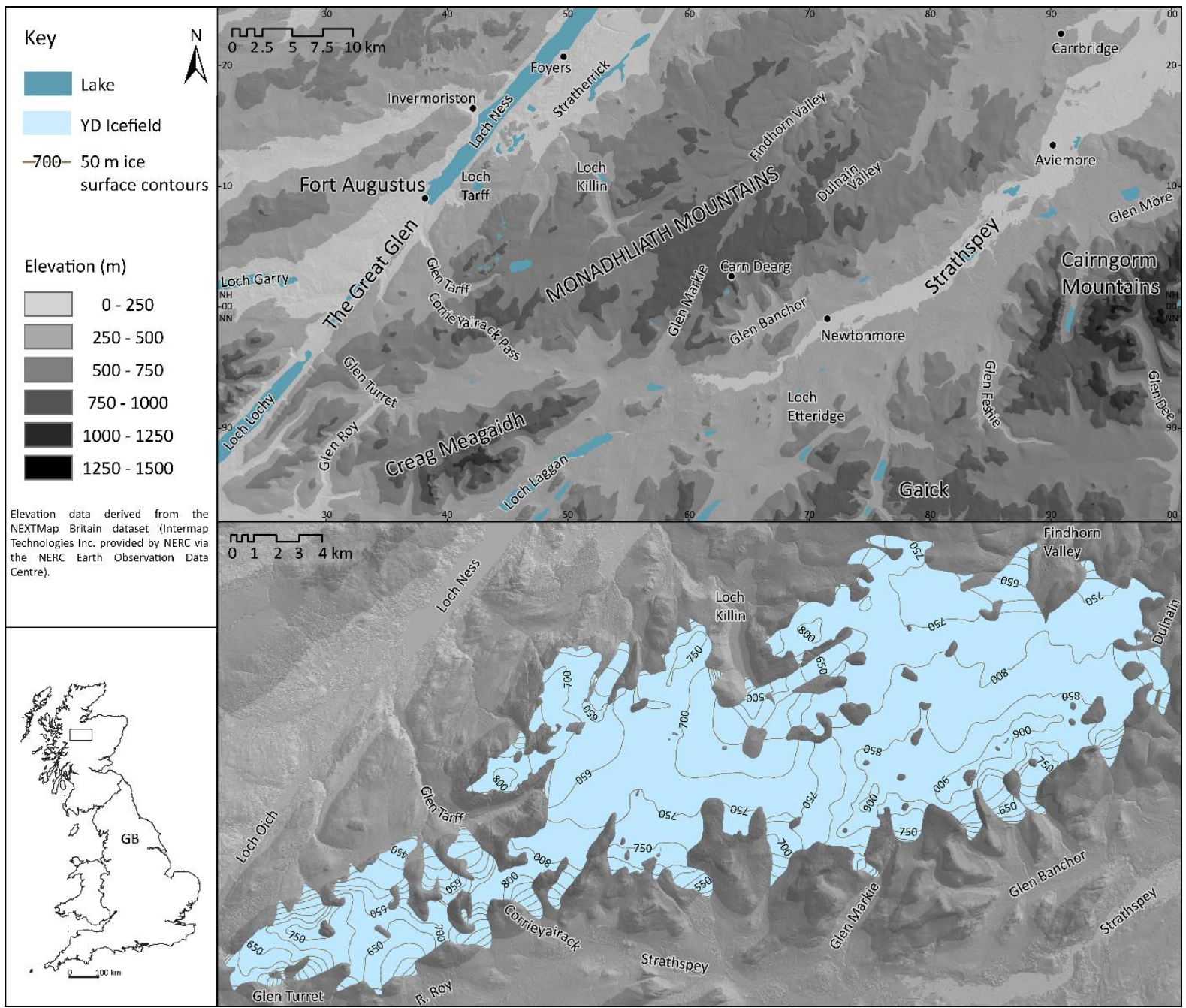

Figure 1. Topographic map of the Monadhliath study area, including the Younger Dryas Monadhliath

828 Icefield reconstruction (Boston et al., 2015). 


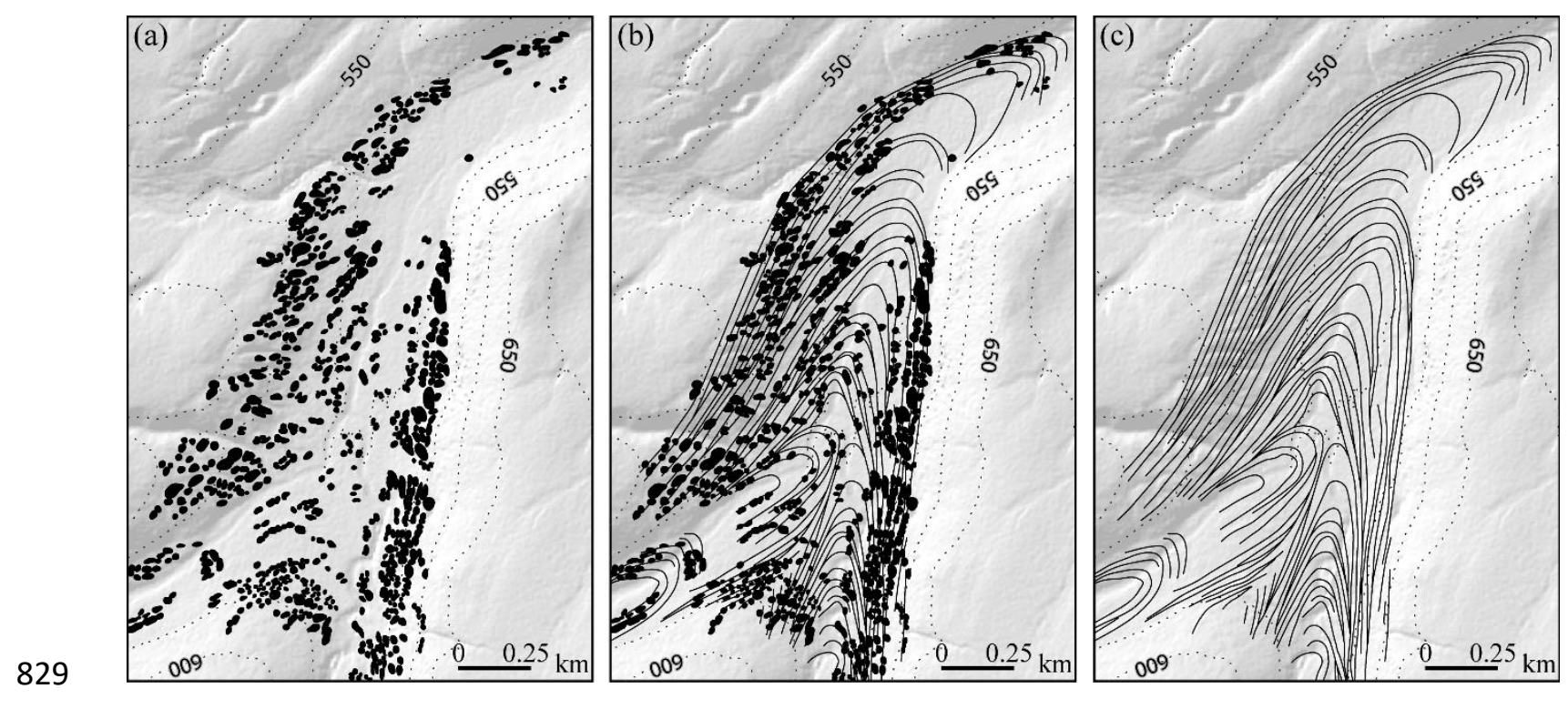

830 Figure 2. Illustration of the approach used to link chains of moraines together, using moraines in the 831 Findhorn Valley near Dalbeg as an example. a) Mapped moraine mounds and ridges. b) Linkage of 832 chains of moraines. c) Reconstructed ice margin positions. 


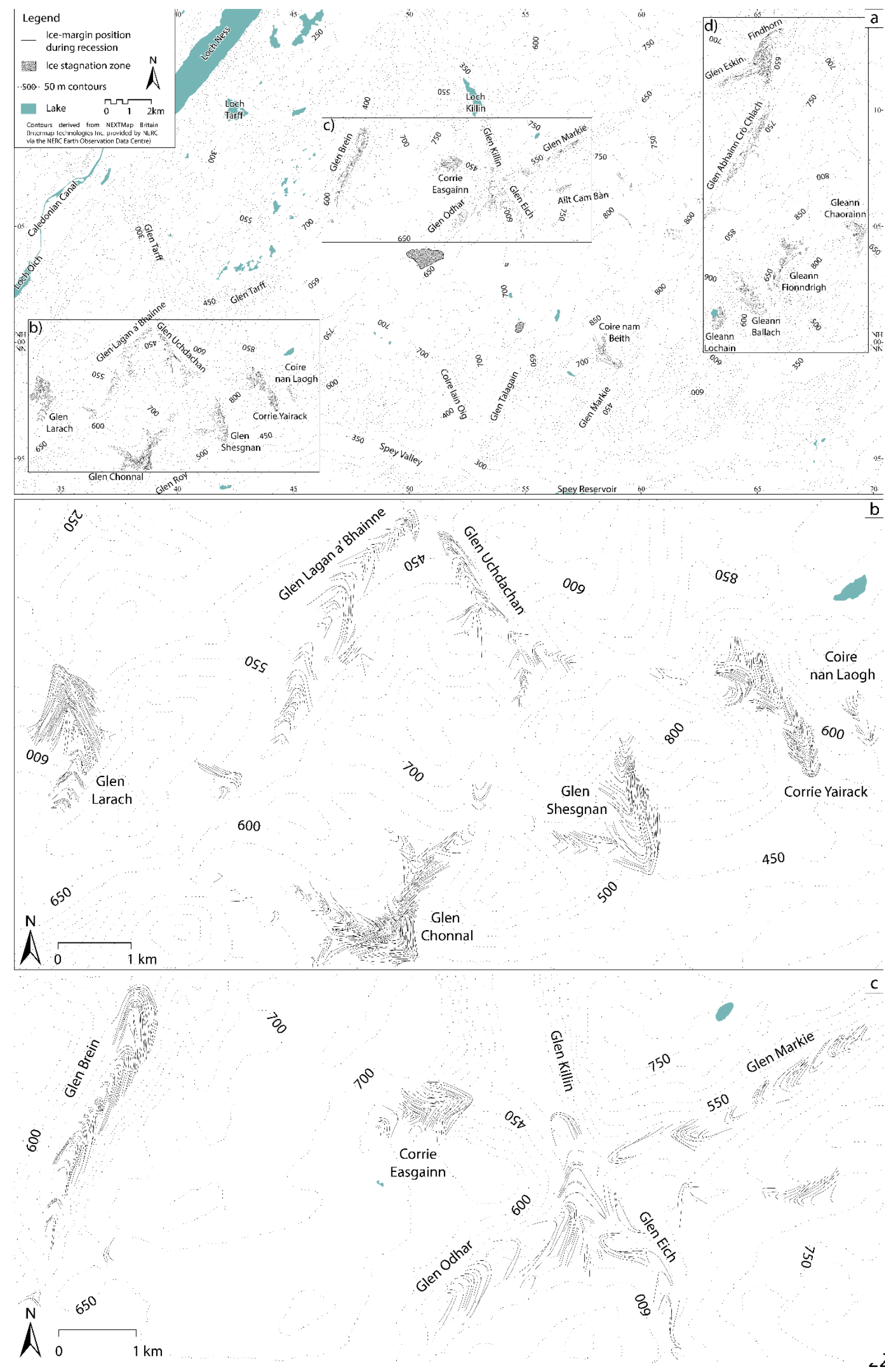




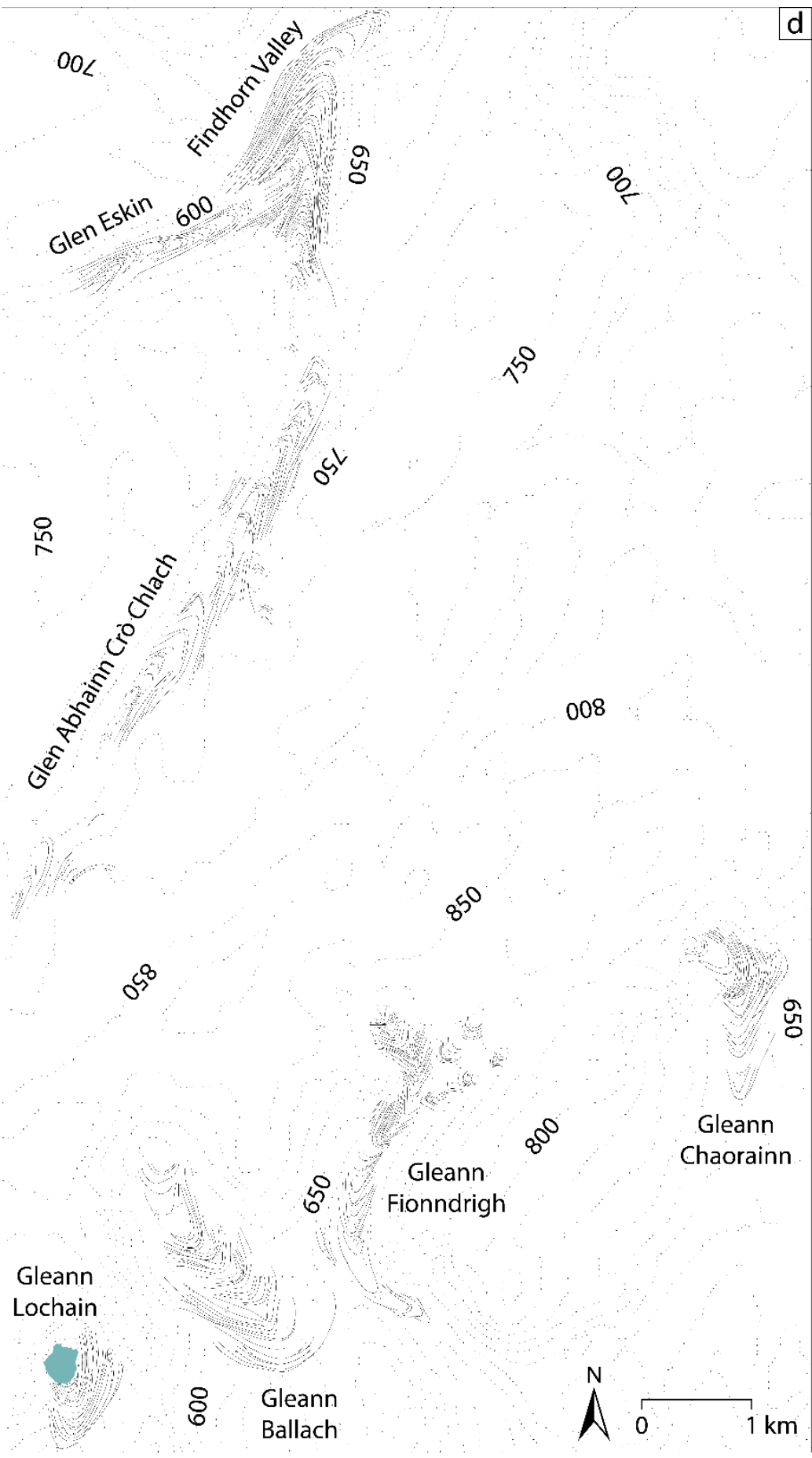

Figure 3. a) Reconstructed ice margins for outlet glaciers in the Monadhliath Mountains that produced recessional moraines, with insets for the b) western, c) central and d) eastern valleys. 

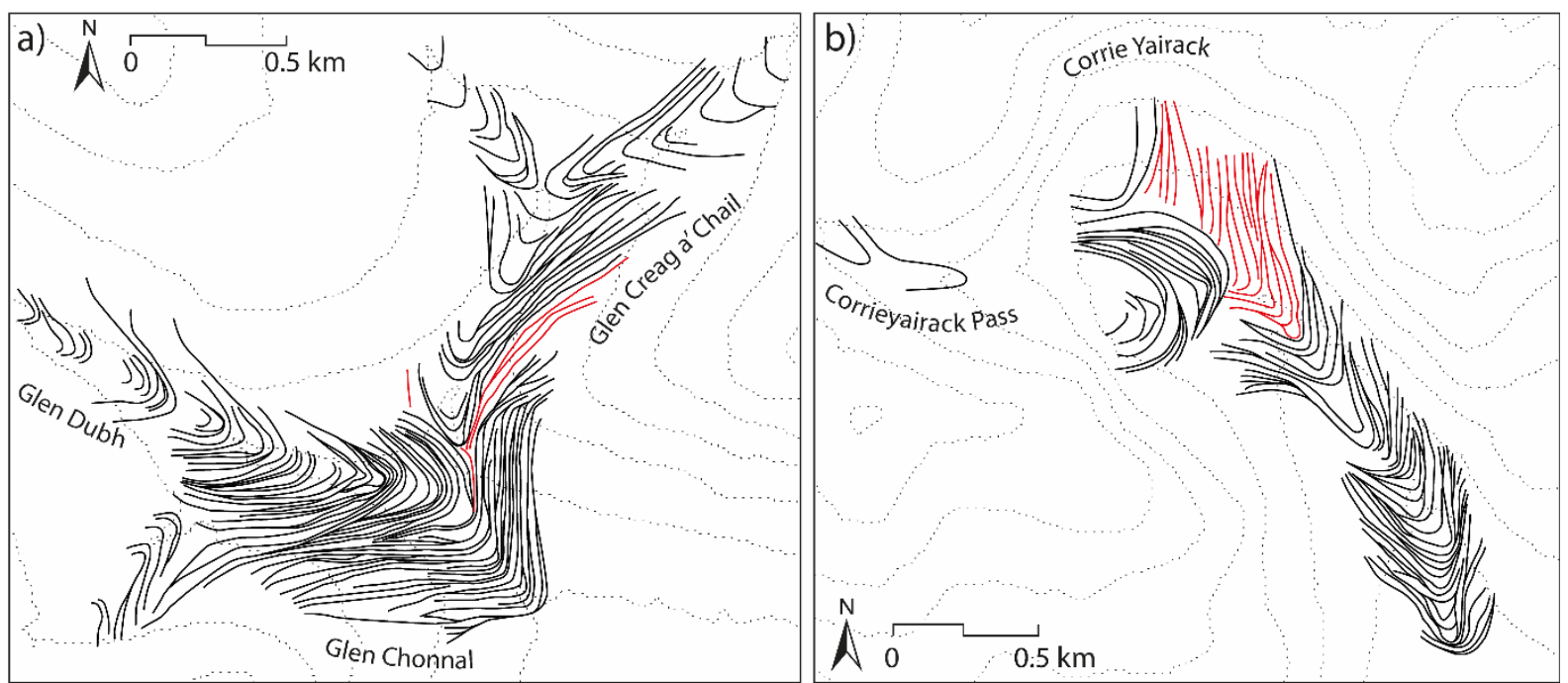

Figure 4. Patterns of ice margin recession in a) Glen Chonnal and b) Corrie Yairack, showing areas where ice margins are truncated (highlighted in red) due to a readvance. The mapped moraines and linkage of moraine chains can be found in SI Figs. S5 and S15.
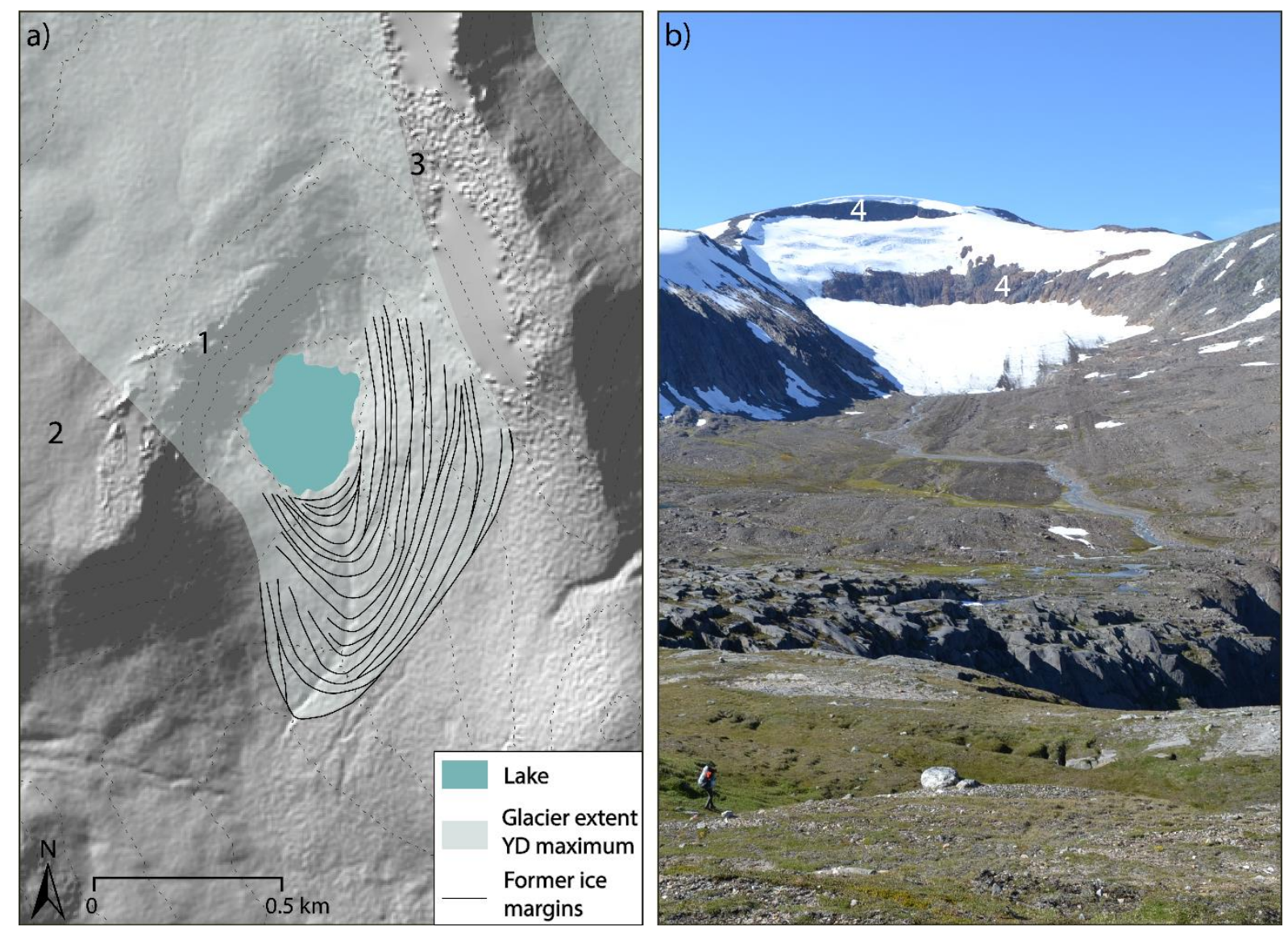

Figure 5. a) Pattern of ice recession and topographic setting that is interpreted as leading to either full or partial disconnection of plateau ice from ice at the cirque head, where (1) indicates the zone of potential detachment. Specific to this example, (2) marks a zone where plateau ice may have also been present, but there is no geomorphological evidence (both on the plateau and based on ice configuration in the neighbouring valleys) to support it; (3) marks the downslope limit of a talus slope (see Boston, 2012), which provides a clear indication of ice thickness on the plateau. b) Cirque 
glacier to the northwest of $\varnothing$ stre Svartisen, Norway, which has begun to disconnect (4) from its source area around Spidstinden (photo credit: Harold Lovell).
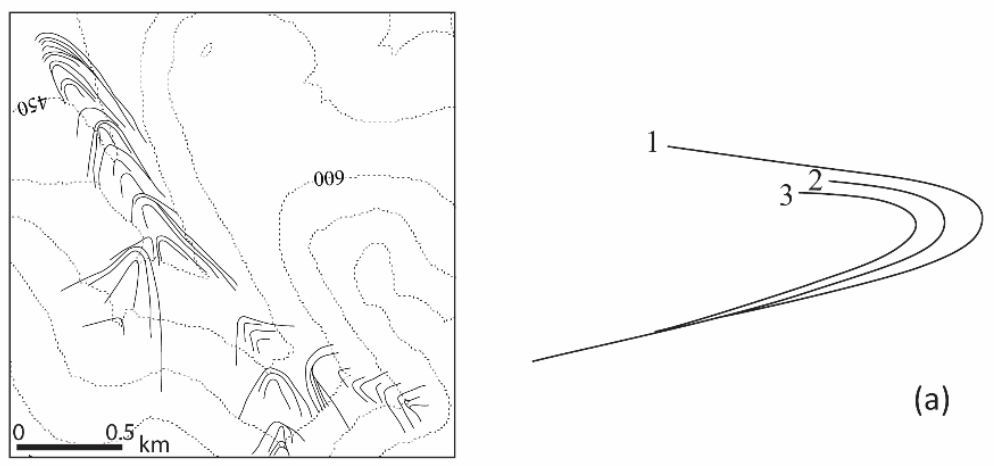

(a)
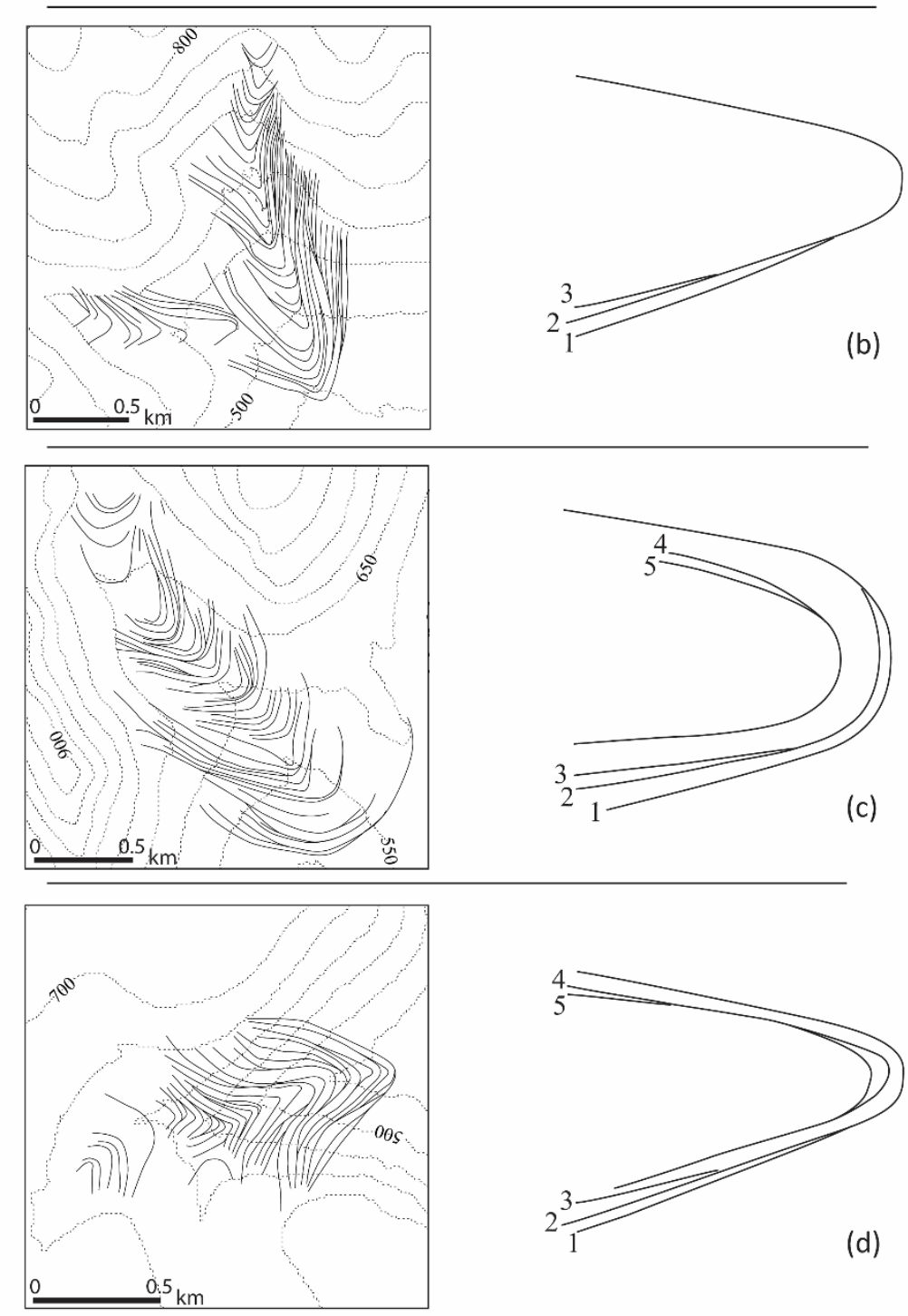

Figure 6. Styles of moraine crestline bifurcation found in the study area: a) frontal bifurcations, where ice thickness further up glacier remains stable, whilst the glacier terminus retreats (example: Uchdachan), b) lateral bifurcations, where the glacier thins, but the terminus remains in the same position; this often occurs close to the plateau edge (example: Shesgnan), c) recession pattern dominated by lateral bifuractions in wide, open valleys, where there is more accommodation space 


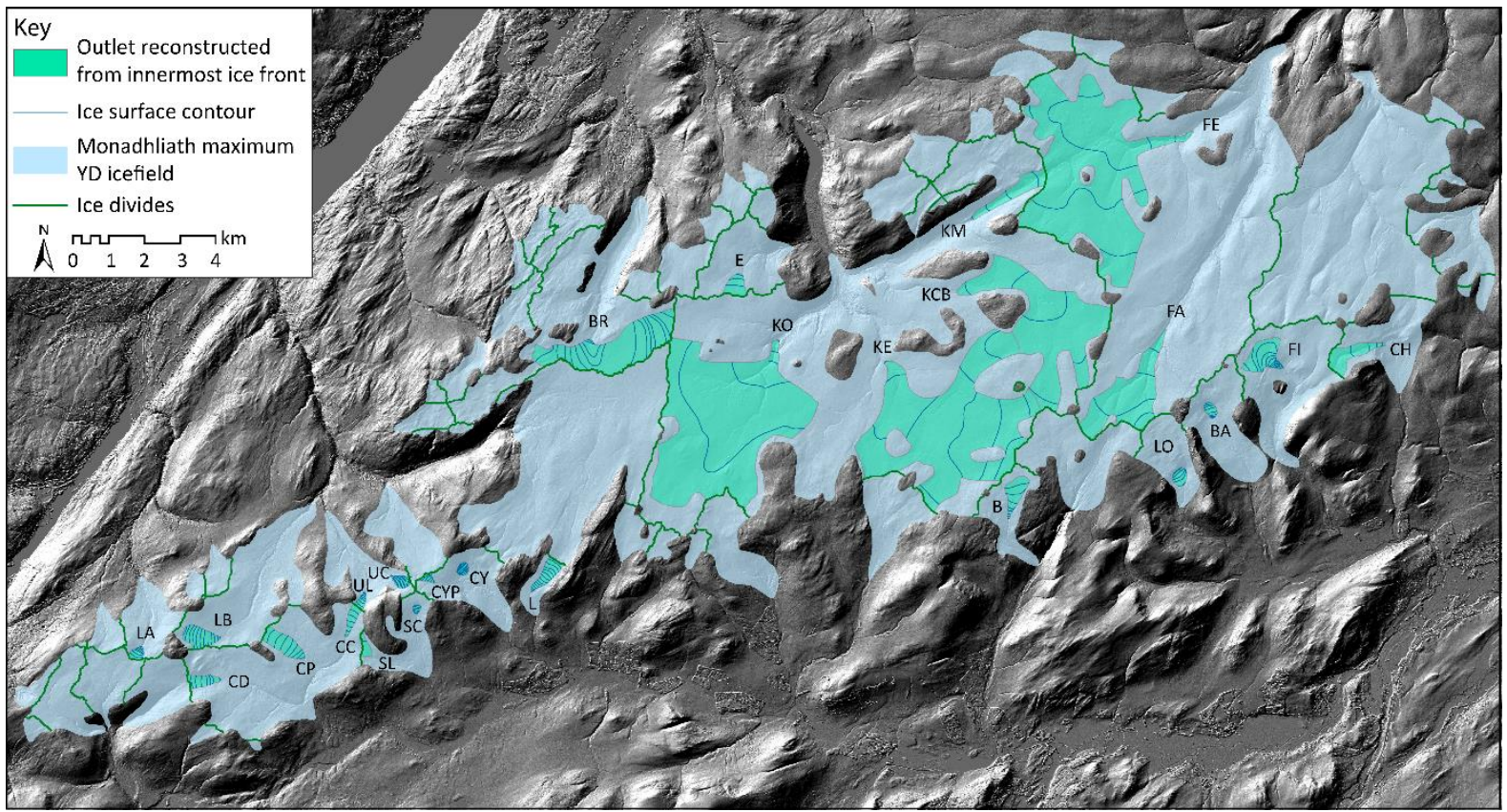

Figure 8. Reconstructed 'final stage' outlet glaciers (in green), showing the approximate dimensions of the ice bodies when the innermost moraines in their respective catchments were produced. Ice divides are based on current watershed. Glacier labels, LA: Larach, LB: Lagan a' Bhainne, CD: Chonnal Dubh, CP: Chonnal Poll-gormack, CC: Chonnal Coire Chail, UL: Uchdachan Leac, UC: Uchdachan Coire, SL: Shesgnan Cuil, SC: Shesgnan Coire, CYP: Corrieyairack Pass, CY: Corrie Yairack, L: Laogh, BR: Brein, E: Easgainn, KO, Killin Odhar, KE: Killin Eich, KCB: Killin Cam Ban, KM: Killin Markie, FE: Findhorn Eskin, FA: Findhorn Abhainn Crò Chlach, B: Beith, LO: Lochain, BA: Ballach, FI: Fiondrigh, CH: Chaorainn.

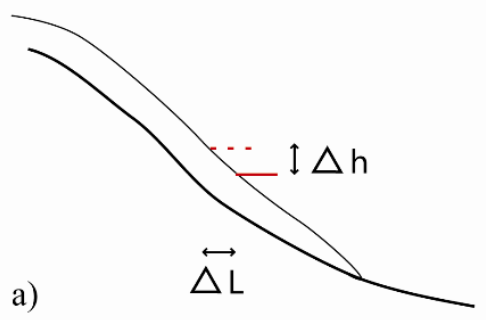

Figure 9. Diagram to show the effect of slope on changes in the position of the ELA, where the same vertical rise in ELA will increase the size of the ablation area more on a flatter glacier than on a steeper one. The solid red line represents the original ELA, the dotted red line represents the new $E L A, \Delta h$ is the change in ELA elevation and $\Delta \mathrm{L}$ is the distance travelled by the ELA in a horizontal direction, which will eventually be translated into a glacier length change visible at the margin. 


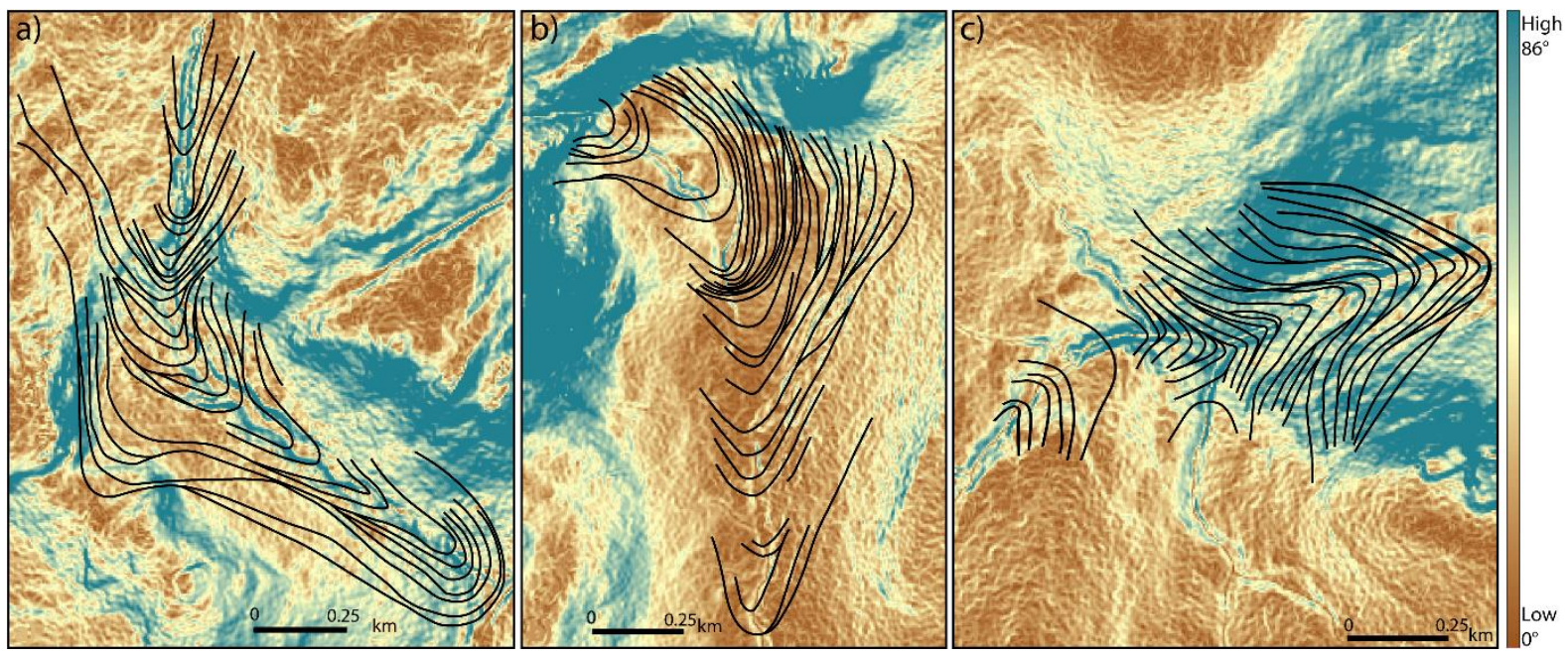

882 Figure 10. Ice margins during retreat for a) Beith Glacier, b) Chaorainn Glacier, c) Easgainn Glacier, 883 overlain onto a slope model. The Beith Glacier displays outermost recession style 1 and demonstrates the influence of slope as ice margins are more closely-spaced on steeper slopes. The Chaorainn Glacier distal recession style 2 and residing in a wide, low gradient valley. However, as the glacier recedes towards the backwall the ice margins become closer due to the steeper gradient and a progressively shorter response time. The Easgainn Glacier is located in an outlet valley of relatively uniform steepness, close to the plateau edge and displays recession style 3 in the outermost zone. As the bed gradient reduces, the ice margins become further apart. Slope data derived from the NEXTMap DSM (Intermap Technologies Inc. provided by NERC via the NERC Earth Observation Data Centre). 
1. Catchments with backwalls
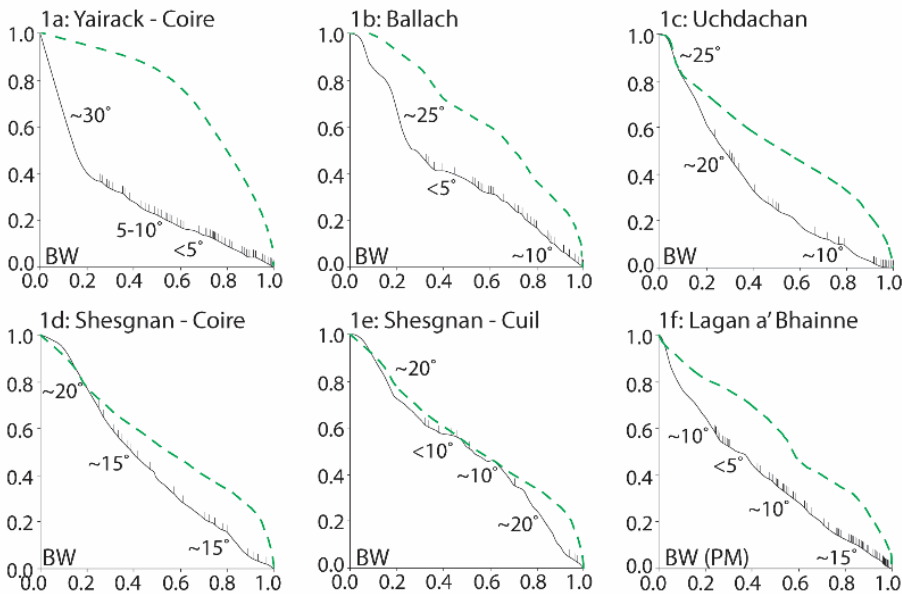

2. Catchments with moraines on plateau
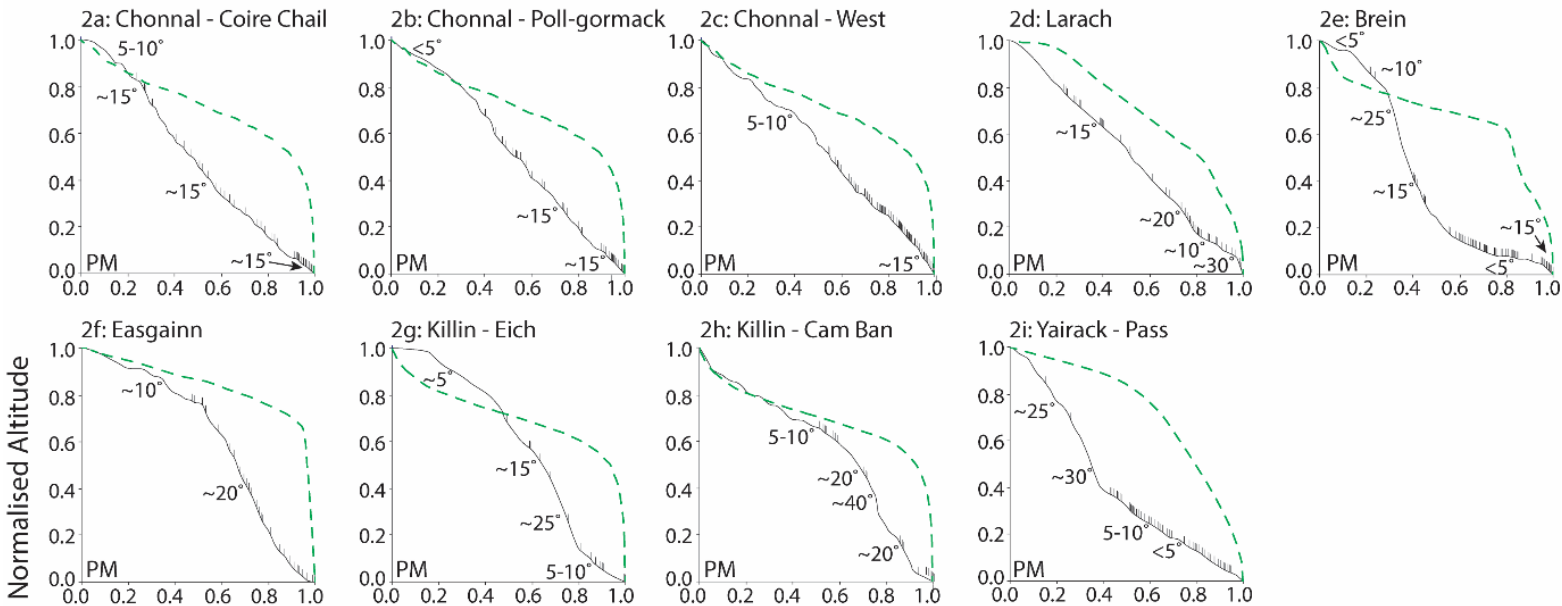

3. Catchments with no moraines on plateau
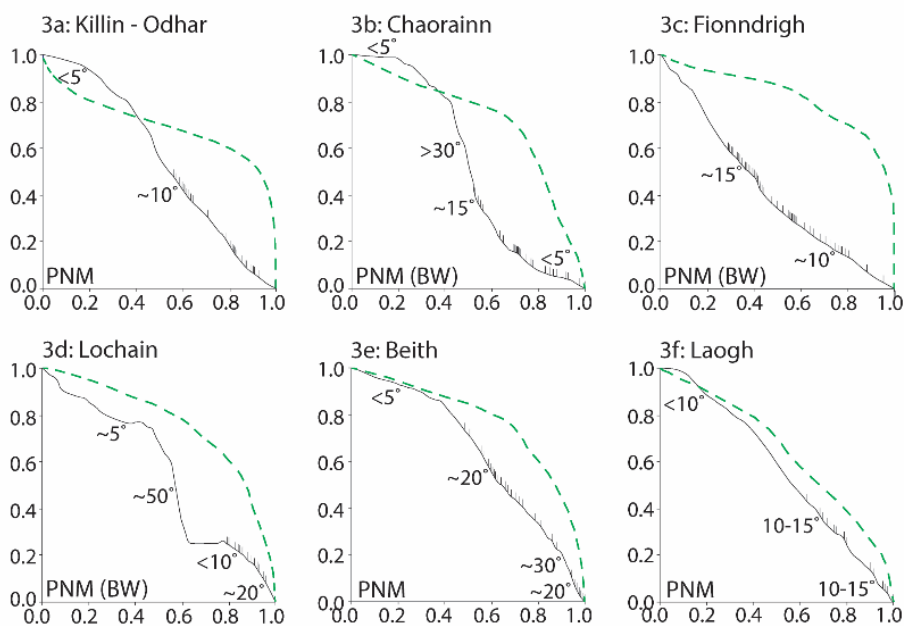

4. Catchments with transection valleys
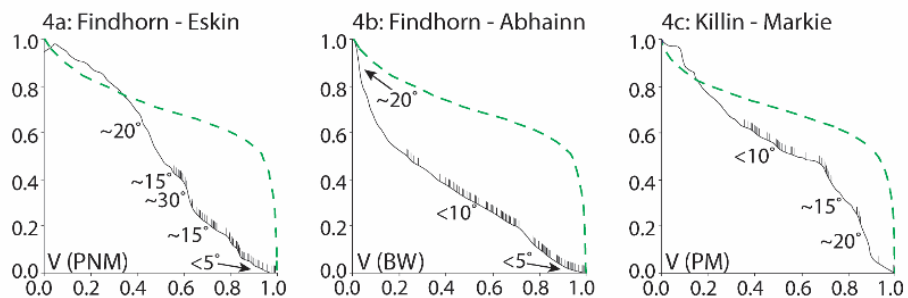
Figure 11. 'Barcodes' and hypsometric curves (dashed green line) for each outlet glacier. The barcodes are overlain onto normalised bed topography along the inferred central flowline of each respective outlet glacier from the terminus (1.0) up to the ice divide. The bed topography profiles are organised by overall retreat pattern groups as described in the text, where BW = backwall, PM = plateau moraines, $\mathrm{PNM}=$ plateau no moraines and $\mathrm{V}=$ valley. If a recession pattern fits into more than one category the secondary group is shown in brackets. The gradient of the bed is indicated in degrees at key locations along each profile.

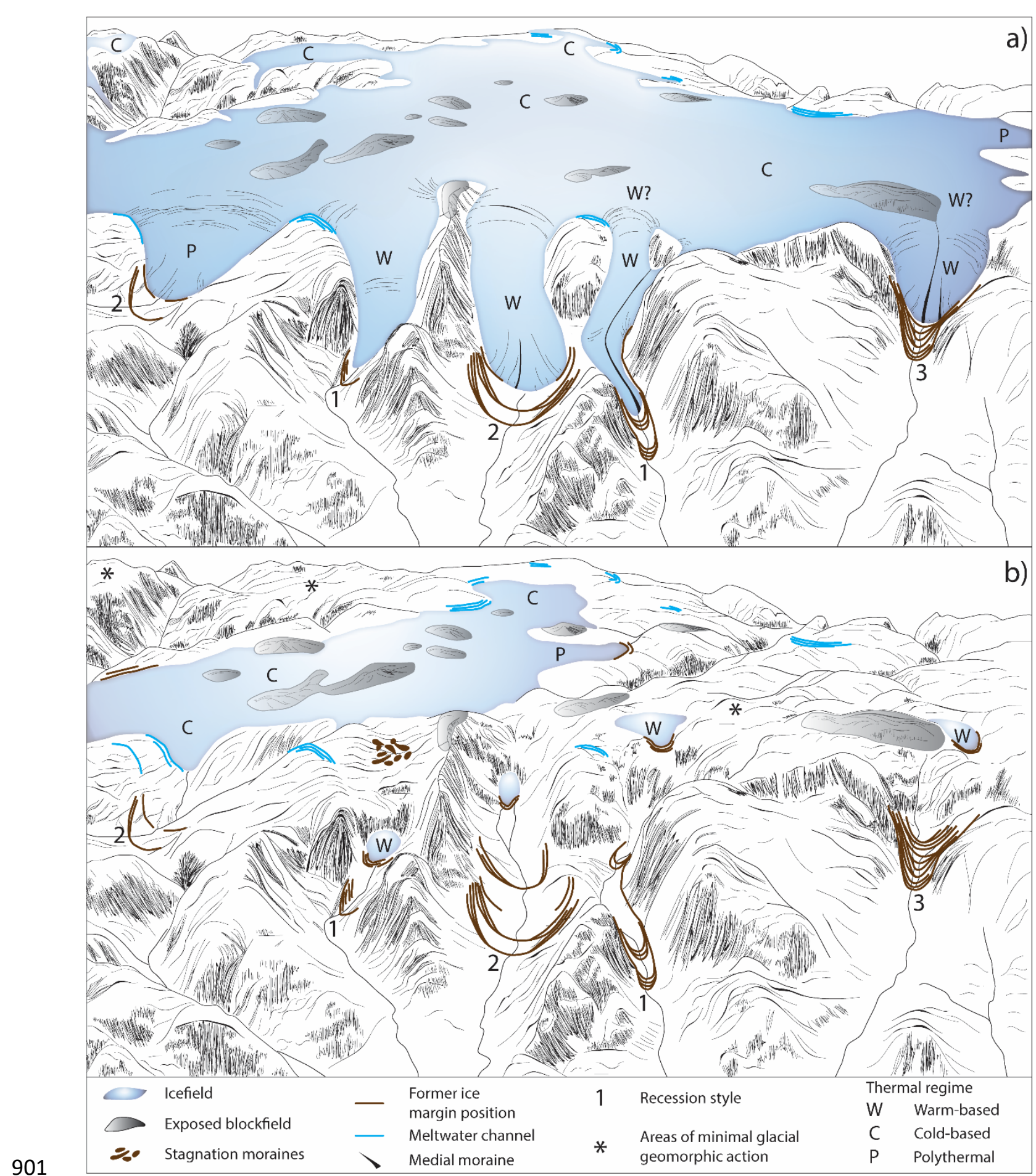


Figure 12. Conceptual diagram of a polythermal plateau icefield landsystem illustrating the different types of geomorphological signature and styles of recession that can occur on plateau icefields due to thermal regime and plateau/valley morphology. a) At the maximum extent, warm-based outlet glaciers (W) will deposit recessional moraines, cold-based outlet glaciers (C) will produce a network of ice-marginal meltwater channels, and polythermal outlet glaciers $(P)$ will leave meltwater channels interspersed with a few small moraines. The recession style immediately inside the maximum extent is controlled by valley morphology, where (1) depicts a recession style dominated by frontal moraine bifurcations within narrow valleys, (2) represents retreat within wider, often flatter valleys, in which lateral moraine bifurcations occur and (3) occurs within valleys that are more closely connected to the plateau, producing both lateral and frontal moraine bifurcations. b) During recession, the plateau icefield will break up into smaller outlet lobes that recede into small protovalleys on the plateau. Disconnection of ice at the valley heads from plateau ice is also possible. Recessional moraines, stagnation moraines and ice-marginal meltwater channels are formed on the plateau at this stage of recession, dependant on whether the outlet glaciers are warm-based and continue to retreat actively. Blockfields are often revealed following plateau icefield retreat, where they have survived beneath cold-based ice.

\section{References}

Åkesson, H, Nisancioglu, KH, Giesen, RH, Morlighem, M. 2017. Simulating the evolution of Hardangerjøkulen ice cap in southern Norway since the midHolocene and its sensitivity to climate change. The Cryosphere $11: 281-302$.

Anderson, LS, Roe, GH, Anderson, RS. 2014. The effects of interannual climate variability on the moraine record. Geology $42: 55-58$.

Bahr, DB, Pfeffer, WT, Sassolas, C, Meier, MF. 1998. Response time of glaciers as a function of size and mass balance: 1. theory. Journal of Geophysical Research $103:$ : 9777-9782.

Bakke, J, Lie, Ø, Heegaard, E, Dokken, T, Haug, GH, Birks, HH, Dulski, P, Nilsen, T. 2009. Rapid oceanic and atmospheric changes during the Younger Dryas cold period. Nature Geoscience 2 : 202-205.

Ballantyne, CK. 2002. The Loch Lomond Readvance on the Isle of Mull, Scotland: glacier reconstruction and palaeoclimatic implications. Journal of Quaternary Science 17 : 759-771.

Ballantyne, CK. 2012. Chronology of glaciation and deglaciation during the Loch Lomond (Younger Dryas) Stade in the Scottish Highlands: implications of recalibrated 10Be exposure ages. Boreas $41: 513-526$.

Barr, ID, Clark, CD. 2012. Late Quaternary glaciations in Far NE Russia; combining moraines, topography and chronology to assess regional and global glaciation synchrony. Quaternary Science Reviews 53 : 72-87.

Barr, ID, Lovell, H. 2014. A review of topographic controls on moraine distribution. Geomorphology 226 : 44-64.

Benn, DI. 1992. The genesis and significance of hummocky moraine - evidence from the Isle of Skye, Scotland. Quaternary Science Reviews 11 : 781-799.

Benn, DI, Lowe, JJ, Walker, MJC. 1992. Glacier response to climatic-change during the Loch-Lomond Stadial and early Flandrian - Geomorphological and 
palynological evidence from the Isle-of-Skye, Scotland. Journal of Quaternary Science 7 : 125-144.

Benn, DI, Evans, DJA. 2008. A Younger Dryas ice cap to the north of Glen Roy: a new perspective on the origin of the Turret Fan. In The Quaternary of Glen Roy and Vicinity: Field Guide, Palmer, AP, Lowe, JJ, Rose, J (eds.). Quaternary Research Association: London; 158-161.

Benn, DI, Lukas, S. 2006. Younger Dryas glacial landsystems in North West Scotland: an assessment of modern analogues and palaeoclimatic implications. Quaternary Science Reviews 25 : 2390-2408.

Bennett, MR. 1999. Paraglacial and periglacial slope adjustment of a degraded lateral moraine in Glen Torridon. Scottish Journal of Geology 35 : 79-83.

Bennett, MR, Boulton, GS. 1993. A reinterpretation of Scottish 'hummocky moraine' and its significance for the deglaciation of the Scottish Highlands during the Younger Dryas or Loch Lomond Stadial. Geological magazine 130 : 301-318.

Bickerdike, HL, Evans, DJA, Stokes, CR, Ó Cofaigh, C. 2018a. The glacial geomorphology of the Loch Lomond (Younger Dryas) Stadial in Britain: a review. Journal of Quaternary Science 33 : 1-54.

Bickerdike, HL, Ó Cofaigh, C, Evans, DJA, Stokes, CR. 2018b. Glacial landsystems, retreat dynamics and controls on Loch Lomond Stadial (Younger Dryas) glaciation in Britain. Boreas 47 : 202-224.

Boston, CM. 2012. A glacial geomorphological map of the Monadhliath Mountains, Scotland. Journal of Maps 8 : 437-444.

Boston, CM, Lukas, S. 2013. The sedimentology of Younger Dryas moraines in the vicinity of Loch Killin. In The Quaternary of the Monadhliath Mountains and the Great Glen: field guide , Boston, CM, Lukas, S, Merritt, JW (eds). Quaternary Research Association: London; 121-127.

Boston, CM, Lukas, S. 2017. Evidence for restricted Loch Lomond Stadial plateau ice in Glen Turret and implications for the age of the Turret Fan. Proceedings of the Geologists' Association 128 : 42-53.

Boston, CM, Lukas, S, Carr, S. 2015. A Younger Dryas plateau icefield in the Monadhliath, Scotland, and implications for regional palaeoclimate. Quaternary Science Reviews 108 139-162.

Boulton, GS. 1986. Push moraines and glacier contact fans in marine and terrestrial environments. Sedimentology 33 : 677-698.

Bradwell, T, Sigurðsson, O, Everest, J. 2013. Recent, very rapid retreat of a temperate glacier in SE Iceland. Boreas 42 : 959-973.

Braun, C, Hardy, DR, Bradley, RS. 2004. Mass balance and area changes of four High Arctic plateau ice caps, 1959-2002. Geografiska Annaler 86A : 43-52.

Bromley, GRM, Putnam, AE, Rademaker, KM, Lowell, TV, Schaefer, JM, Hall, B, Winckler, G, Birkel, SD, Borns, HW. 2014. Younger Dryas deglaciation of Scotland driven by warming summers. Proceedings of the National Academy of Sciences $111: 6215-6219$.

Brooks, SJ, Davies, KL, Mather, KA, Matthews, IP, Lowe, JJ. 2016. Chironomidinferred summer temperatures for the Last Glacial-Interglacial Transition from a lake sediment sequence in Muir Park Reservoir, west-central Scotland. Journal of Quaternary Science 31 : 214-224. 
Chandler, BMP. 2018. Extent, style and timing of former glaciation in the Gaick, central Grampians, Scotland, and implications for palaeoclimate. Unpublished PhD thesis, Queen Mary University of London, $339 \mathrm{pp}$.

Chandler, BMP, Evans, DJA, Roberts, DH. 2016. Characteristics of recessional moraines at a temperate glacier in SE Iceland: Insights into patterns, rates and drivers of glacier retreat. Quaternary Science Reviews 135 : 171-205.

Chandler, BMP, Lovell, H, Boston, CM, Lukas, S, Barr, ID, Benediktsson, ÍÖ, Benn, DI, Clark, CD, Darvill, CM, Evans, DJ, Ewertowski, MW. 2018. Glacial geomorphological mapping: A review of approaches and frameworks for best practice. Earth-Science Reviews 185 : 806-846.

Chandler, BMP, Lukas, S, Boston, CM, Merritt, JW. 2019a. Glacial geomorphology of the Gaick, Central Grampians, Scotland. Journal of Maps 15 : 61-79.

Chandler, BMP, Boston, CM, Lukas, S. 2019b. A spatially-restricted Younger Dryas plateau icefield in the Gaick, Scotland: Reconstruction and palaeoclimatic implications. Quaternary Science Reviews 211 : 107-135.

Christiansen, HH. 2004. Windpolished boulders and bedrock in the Scottish Highlands: evidence and implications of Late Devensian wind activity. Boreas $\mathbf{3 3}$ : 82-94.

Curry, AM, Cleasby, V, Zukowskyj, P. 2006. Paraglacial response of steep, sedimentmantled slopes to post-'Little Ice Age' glacier recession in the central Swiss Alps. Journal of Quaternary Science $21: 211-225$.

Davies, BJ, Glasser, NF. 2012. Accelerating shrinkage of Patagonian glaciers from the Little Ice Age ( AD 1870) to the present day. Journal of Glaciology 58 : 10631084.

de Winter, IL, Storms, JEA, Overeem, I. 2012. Numerical modeling of glacial sediment production and transport during deglaciation. Geomorphology 167-168 : 102-114.

Dugmore, AJ, Sugden, DE. 1991. Do the anomalous fluctuations of Solheimajökull reflect ice-divide migration? Boreas 20 : 105-113.

Dyke, AS. 1993. Landscapes of cold-centred Late Wisconsinan ice caps, Arctic Canada. Progress in Physical Geography 17 : 223-247.

Evans, DJA. 2010. Controlled moraine development and debris transport pathways in polythermal plateau icefields: examples from Tungnafellsjökull, Iceland. Earth Surface Processes and Landforms 35 : 1430-1444.

Evans, DJA. 2016. Landscapes at the Periphery of Glacierization - Retrospect and Prospect. Scottish Geographical Journal 132 : 140-163.

Evans, DJA, Rea, BR, Hansom, JD, Whalley, WB. 2002. Geomorphology and style of plateau icefield deglaciation in fjord terrains: the example of Troms-Finnmark, north Norway. Journal of Quaternary Science $17: 221-239$.

Evans, DJA, Twigg, DR. 2002. The active temperate glacial landsystem: a model based on Breiðamerkurjökull and Fjallsjökull, Iceland. Quaternary science reviews $21: 2143-2177$.

Evans, DJA, Twigg, DR, Shand, M. 2006. Surficial geology and geomorphology of the pórisjökull plateau icefield, west-central Iceland. Journal of Maps 2006 : 17-29.

Finlayson, A, Golledge, N, Bradwell, T, Fabel, D. 2011. Evolution of a Lateglacial mountain ice cap in northern Scotland. Boreas 40 : 536-554. 
Furbish, DJ, Andrews, JT. 1984. The use of hypsometry to indicate long-term stability and response of valley glaciers to changes in mass transfer. Journal of Glaciology $30: 199-211$.

Gellatly, AF, Whalley, B, Gordon, JE. 1986. Topographic control over recent glacier changes in southern Lyngen Peninsula, North Norway. Norsk Geografisk Tidsskrift $40: 211-218$.

Gellatly, AF, Gordon, JE, Whalley, WB, Hansom, JD. 1988. Thermal regime and geomorphology of plateau ice caps in northern Norway: observations and implications. Geology 16 : 983-986.

Gheorghiu, DM, Fabel, D, Hansom, JD, Xu, S. 2012. Lateglacial surface exposure dating in the Monadhliath Mountains, Central Highlands, Scotland. Quaternary Science Reviews 41 : 132-146.

Giesen, RH, Oerlemans, J. 2010. Response of the ice cap Hardangerjøkulen in southern Norway to the 20th and 21 st century climates. The Cryosphere 4 : 191213.

Golledge, NR, Hubbard, A. 2005. Evaluating Younger Dryas glacier reconstructions in part of the western Scottish Highlands: a combined empirical and theoretical approach. Boreas 34 : 274-286.

Golledge, NR, Hubbard, A, Sugden, DE. 2008. High-resolution numerical simulation of Younger Dryas glaciation in Scotland. Quaternary Science Reviews 27 : 888904.

Gordon, JE, Whalley, B, Gellatly, AF. 1995. Fluctuations of glaciers in Lyngsdalen, Troms, Norway, during the $20^{\text {th }}$ Century. Zeitschrift für Gletscherkunde und glazialgeologie 31 : 125-134.

Greene, D. 1992. Topography and former Scottish tidewater glaciers. Scottish Geographical Magazine 108 : 164-171.

Hubbard, A, Bradwell, T, Golledge, N, Hall, A, Patton, H, Sugden, D, Cooper, R, Stoker, M. 2009. Dynamic cycles, ice streams and their impact on the extent, chronology and deglaciation of the British-Irish ice sheet. Quaternary Science Reviews 28 : 758-776.

Intermap Technologies, 2007. NEXTMap British Digital Terrain Model Dataset Produced by Intermap. NERC Earth Observation Data Centre 2016. http://catalogue.ceda.ac.uk/uuid/8f6e1598372c058f07b0aeac2442366d

Iturrizaga, L. 2008. Post-sedimentary Transformation of Lateral Moraines - the Tributary Tongue Basins of the Kvíárjökull (Iceland). Journal of Mountain Science $5: 1-16$.

Ivy-Ochs, S, Kerschner, H, Maisch, M, Christl, M, Kubik, PW, Schlüchter, C. 2009. Latest Pleistocene and Holocene glacier variations in the European Alps. Quaternary Science Reviews 28 : 2137-2149.

Jiskoot, H, Curran, CJ, Tessler, DL, Shenton, LR. 2009. Changes in Clemenceau Icefield and Chaba Group glaciers, Canada, related to hypsometry, tributary detachment, length-slope and area-aspect relations. Annals of Glaciology 50 : 133-143.

Kirkbride, MP, Winkler, S. 2012. Correlation of Late Quaternary moraines: impact of climate variability, glacier response, and chronological resolution. Quaternary Science Reviews 46 : 1-29. 
Kuhn, M, Markl, G, Kaser, G, Nickus, U, Obleitner, F, Schneider, H. 1985. Fluctuations of climate and mass balance: Different responses of two adjacent glaciers. Zeitschrift für Gletscherkunde und Glazialgeologie 21 : 409-416.

Lane, CS, Brauer, A, Blockley, PE, Dulski, P. 2013. Volcanic ash reveals timetransgressive abrupt climate change during the Younger Dryas. Geology 41 : 1251-1254.

Larsen, NK, Funder, S, Linge, H, Möller, P, Schomacker, A, Fabel, D, Xu, S, Kjær, $\mathrm{KH}$. 2016. A Younger Dryas re-advance of local glaciers in north Greenland. Quaternary Science Reviews 147 : 47-58.

Levy, LB, Kelly, MA, Lowell, TV, Hall, BL, Hempel, LA, Honsaker, WM, Lusas, AR, Howley, JA, Axford, YL. 2014. Holocene fluctuations of Bregne ice cap, Scoresby Sund, east Greenland: a proxy for climate along the Greenland Ice Sheet margin. Quaternary Science Reviews 92 : 357-368.

López-Moreno, JI, Nogués-Bravo, D, Chueca-Cía, J, Julián-Andrés, A. 2006. Change in topographic control on the extent of cirque glaciers since the Little Ice Age. Geophysical Research Letters 33 : L24505. Doi: 10.1029/2006GL028204

Lovell, H, Fleming, EJ, Benn, DI, Hubbard, B, Lukas, S, Naegeli, K. 2015. Former dynamic behaviour of a cold-based valley glacier on Svalbard revealed by basal ice and structural glaciology investigations. Journal of Glaciology 61 : 309-328.

Lowe, JJ, Rasmussen, SO, Björck, S, Hoek, WZ, Steffensen, JP, Walker, MJC, Yu, ZC, group, t.I. 2008. Synchronisation of palaeoenvironmental events in the North Atlantic region during the Last Termination: a revised protocol recommended by the INTIMATE group. Quaternary Science Reviews 27 : 6-17.

Lukas, S. 2003. The moraines around the pass of Drumochter. Scottish Geographical Journal 119 : 383-393.

Lukas, S. 2005. A test of the englacial thrusting hypothesis of 'hummocky'moraine formation: case studies from the northwest Highlands, Scotland. Boreas 34 : 287307.

Lukas, S. 2006. Morphostratigraphic principles in glacier reconstruction - a perspective from the British Younger Dryas. Progress in Physical Geography 30 : 719-736.

Lukas, S. 2007a. 'A test of the englacial thrusting hypothesis of "hummocky" moraine formation: case studies from the northwest Highlands, Scotland': Reply to comments. Boreas $36: 108-133$.

Lukas, S. 2007b. Early-Holocene glacier fluctuations in Krundalen, south central Norway: palaeo-glacier dynamics and palaeoclimate. The Holocene 17 : 585598.

Lukas, S. 2012. Processes of annual moraine formation at a temperate alpine valley glacier: insights into glacier dynamics and climatic controls. Boreas 41 : 463-480.

Lukas, S, Benn, DI. 2006. Retreat dynamics of Younger Dryas glacier in the far NW Scottish Highlands reconstructed from moraine sequences. Scottish Geographical Journal 122 : 308-325.

Lukas, S, Bradwell, T. 2010. Reconstruction of a Lateglacial (Younger Dryas) mountain ice field in Sutherland, NW Scotland, and its palaeoclimatic implications. Journal of Quaternary Science 25 : 567-580.

Lukas, S, Preusser, F, Evans, DJA, Boston, CM, Lovell, H. 2017. The Quaternary. In Engineering Geology and Geomorphology of Glaciated and Periglaciated 
Terrains: Engineering Group Working Party Report Griffiths, JS, Martin, CJ (eds). Geological Society, London, Engineering Geology Special Publications 28 : 31 57.

Mackintosh, AN, Anderson, BM, Pierrehumbert, RT. 2017. Reconstructing climate from glaciers. Annual Review of Earth and Planetary Sciences 45 : 649-680.

MacLeod, A, Matthews, IP, Lowe, JJ, Palmer, AP, Albert, PG. 2015. A second tephra isochron for the Younger Dryas period in northern Europe: the Abernethy Tephra. Quaternary Geochronology 28 : 1-11.

MacLeod, A, Palmer, A, Lowe, J, Rose, J, Bryant, C, Merritt, J. 2011. Timing of glacier response to Younger Dryas climatic cooling in Scotland. Global and Planetary Change 79 : 264-274.

Mangerud, J, Aarseth, I, Hughes, ALC, Lohne, Ø, Skår, K, Sønstegaard, E, Svendsen, JI. 2016. A major re-growth of the Scandinavian Ice Sheet in western Norway during Allerød-Younger Dryas. Quaternary Science Reviews 132 : 175-205.

Manley, G. 1955. On the occurrence of ice domes and permanently snow-covered summits. Journal of Glaciology 2 : 453-456.

Margreth, A, Dyke, AS, Gosse, JC, Telka, AM. 2014. Neoglacial ice expansion and late Holocene cold-based ice cap dynamics on Cumberland Peninsula, Baffin Island, Arctic Canada. Quaternary Science Reviews 91 : 242-256.

Marzeion, B, Jarosch, AH, Gregory, JM. 2014. Feedbacks and mechanisms affecting the global sensitivity of glaciers to climate change. The Cryosphere $8: 59-71$.

McDougall, DA. 2013. Glaciation style and the geomorphological record: evidence for Younger Dryas glaciers in the eastern Lake District, northwest England. Quaternary Science Reviews 73 : 48-58.

Nesje, A, Bakke, J, Dahl, SO, Lie, $\varnothing$, Matthews, JA. 2008. Norwegian mountain glaciers in the past present and future. Global and Planetary Change 60 : 10-27.

Oerlemans, J. 1989. On the response of valley glaciers to climatic change. In Glacier Fluctuations and Climate Change, Oerlemans, J (ed). Springer: Dordrecht; 353371.

Oerlemans, J. 2008. Minimal Glacier Models. Igitur Press: Utrecht.

Oerlemans, J. 2012. Linear modelling of glacier length fluctuations. Geografiska Annaler: Series A, Physical Geography 94 : 183-194.

Palmer, AP, Lowe, JJ. 2017. Dynamic landscape changes in Glen Roy and vicinity, west Highland Scotland, during the Younger Dryas and early Holocene: a synthesis. Proceedings of the Geologists' Association 128 : 2-25.

Paul, F. 2010. The influence of changes in glacier extent and surface elevation on modeled mass balance. The Cryosphere 4 : 569-581.

Peacock, JD, Rose, J. 2017. Was the Younger Dryas (Loch Lomond Stadial) icefield on Rannoch Moor, western Scotland, deglaciated as early as c. 12.5 cal ka BP? Proceedings of the Geologists' Association 128 : 173-179.

Price, RJ. 1970. Moraines at fjallsjökull, Iceland. Arctic and Alpine Research 2 : 27 42.

Purdie, H, Wilson, J, Gomez, C, Stewart, EJ, Espiner, S, Bealing, P, Key, N. 2014. Glacier retreat: feedbacks and implications for glacier tourism. In IAG/NZGS Conference. 
1180

1181

1182

1183

1184

1185

1186

1187

1188

1189

1190

1191

1192

1193

1194

1195

1196

1197

1198

1199

1200

1201

1202

1203

1204

1205

1206

1207

1208

1209

1210

1211

1212

1213

1214

1215

1216

1217

1218

1219

1220

1221

1222

1223

Raper, SCB, Braithwaite, RJ. 2009. Glacier volume response time and its links to climate and topography based on a conceptual model of glacier hypsometry. The Cryosphere 3 : 183-194.

Rasmussen, SO, Andersen, KK, Svensson, AM, Steffensen, JP, Vinther, BM, Clausen, HB, Siggaard-Andersen, M-L, Larsen, LB, Dahl-Jensen, D, Bigler, M, Rothlisberger, R, Fischer, H, Goto-Azuma, K, Hansson, ME, Ruth, U. 2006. A new Greenland ice core chronology for the last glacial termination. Journal of Geophysical Research 111 : D6102, DOI:10.1029/2005JD006079.

Rasmussen, SO, Birks, HH, Blockley, SPE, Brauer, A, Hajdas, I, Hoek, WZ, Lowe, JJ, Moreno, A, Renssen, H, Roche, DM, Svensson, AM, Valdes, P, Walker, MJC. 2014. Dating, synthesis, and interpretation of palaeoclimatic records of the Last Glacial cycle and model-data integration: advances by the INTIMATE (INTegration of Ice-core, MArine and TErrestrial records) COST Action ES0907. Quaternary Science Reviews 106 : 1-13.

Rea, BR. 2009. Defining modern day Area-Altitude Balance Ratios (AABRs) and their use in glacier-climate reconstructions. Quaternary Science Reviews 28 : 237248.

Rea, BR, Evans, DJA. 2003. Plateau icefield landsystems. In Glacial Landsystems, Evans, DJA (ed). Arnold: Oxon; 407-431.

Rea, BR, Evans, DJA. 2007. Quantifying climate and glacier mass balance in north Norway during the Younger Dryas. Palaeogeography, Paleaoclimatology, Palaeoecology 246 : 307-330.

Rea, BR, Walley, BW, Dixon, T, Gordon, JE. 1999. Plateau icefields as contributing areas to valley glaciers and the potential impact on reconstructed ELAs: a case study from the Lyngen Alps, North Norway. Annals of Glaciology 28 : 97-102.

Rea, BR, Walley, BW, Evans, DJA, Gordon, JE, McDougall, DA. 1998. Plateau Icefields: Geomorphology and Dynamics. Quaternary Proceedings 6 : 35-54.

Reinardy, BT, Leighton, I, Marx, PJ. 2013. Glacier thermal regime linked to processes of annual moraine formation at Midtdalsbreen, southern Norway. Boreas 42 : 896-911.

Reinardy, BTI, Booth, A, Hughes, A, Boston, CM, Åkesson, H, Bakke, J, Nesje, A, Giesen, RH, Pearce, D. 2018, in review. Spatial distribution of cold-ice within a temperate glacier - implications for glacier dynamics, sediment transport and foreland geomorphology. The Cryosphere Discuss, https://doi.org/10.5194/tc2018-199

Reitner, JM. 2007. Glacial dynamics at the beginning of Termination I in the Eastern Alps and their stratigraphic implications. Quaternary International $164: 64-84$.

Rowan, AV. 2011. Modelling Geomorphic Systems: Glacial. In Geomorphological Techniques (Online Edition), Cook, SJ, Clarke, LE, Nield, JM (eds). British Society for Geomorphology: London; Chapter 5, Section 5.6.5.

Seguinot, J, Ivy-Ochs, S, Jouvet, G, Huss, M, Funk, M, Preusser, F. 2018. Modelling last glacial cycle ice dynamics in the Alps. The Cryosphere 12 : 3265-3285.

Small, D, Fabel, D. 2016. Was Scotland deglaciated during the Younger Dryas? Quaternary Science Reviews 145 : 259-263. 
Sprenke, KF, Miller, MM, McGee, SR, Adema, GW.,1999. Canadian Landform Examples - 36: The high ice plateau of the Juneau Icefield, British Columbia: Form and Dynamics. The Canadian Geographer 43 : 99-104.

Stephenson, D, Gould, D. 1995. British Regional Geology: the Grampian Highlands. HMSO for the British Geological Survey: London; fourth edition.

Thome, KN. 1972. Asymmetries in glacier-structure and their influence on glaciermovement and glacier-deposits. In 24th International Geological Congress Proceedings. Montreal; 198-211.

Weber, P, Boston CM, Lovell, H, Andreassen, L. in review. Evolution of the Norwegian plateau icefield Hardangerjøkulen since the Little Ice Age. The Holocene.

Wyshnytzky, CE. 2017. On the mechanisms of minor moraine formation in highmountain environments of the European Alps. Unpublished PhD thesis: Queen Mary University of London.

Zekollari, H, Huybrechts, P, Noël, B, van de Berg, WJ, van den Broeke, MR. 2017. Sensitivity, stability and future evolution of the world's northernmost ice cap, Hans Tausen Iskappe (Greenland). The Cryosphere 11 : 805-825. 